
Bartın Üniversitesi
Eğitim Fakültesi Dergisi
Cilt 6, Sayı 3, s.984-1016, Ekim 2017
BARTIN - TÜRKIYE

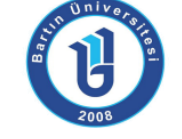

\title{
Resimli Öykü Kitaplarındaki Görseller ve Metinler Masum mu? - Illetilen Doğal Çevre Mesajları
}

Burcu ÇABUK, Arş. Gör. Dr., Ankara Üniversitesi Eğitim Bilimleri Fakültesi, cabuk@education.ankara.edu.tr, http://orcid.org/0000-0003-1166-9773

Tuğba BAŞ, Arş. Gör., Bartın Üniversitesi Eğitim Fakültesi, tugbabass32@gmail.com,

http://orcid.org/0000-0003-1093-2445

Nergiz TEKE, Arş. Gör., Bartın Üniversitesi Eğitim Fakültesi, nergizteke42@gmail.com,

http://orcid.org/0000-0002-7281-7509

Öz: Bu araştırmada, resimli öykü kitaplarında verilen doğal çevre mesajları eleştirel bir bakış açısıyla incelenmekle birlikte temelde okul öncesi dönemdeki çocuklara yönelik hazırlanmış olan kitaplardaki görseller ve metinler aracılığıyla verilen mesajlara odaklanılmaktadır. Görseller ve metinlerde yer alan doğal çevre mesajlarını inceleyen bu nitel araştırmada durum araştırmasıkullanılmıştır. Veriler doküman incelemesi yoluyla, araştırmacılar tarafından geliştirilen 3 form yardımıyla toplanmıştır ve içerik analizi yöntemiyle çözümlenmiştir. Bu amaçla, bir üniversitede yer alan çocuk kütüphanesindeki kitaplar incelenerek kopyaları çıkarıldıktan sonra, kitaplar ilk olarak doğal çevre ile doğrudan ilgili olup olmadığına göre, ikinci olarak da canlı-doğal çevre etkileşimi içerip içermediğine göre değerlendirilmiştir. Araştırmacılar tarafından incelenen toplam 58 kitaba yönelik olarak elde edilen verilerin analizinden önce araştırmacılar geçerlik ve güvenirlik çalışmaları gerçekleştirmişlerdir. Veri analizlerinin sonucunda, yazarların ve çizerlerin resimli öykü kitapları aracılığıyla, okuyuculara verdikleri olumlu doğal çevre mesajlarının yanında, bilinçsizce de olsa, olumsuz doğal çevre mesajları verdikleri belirlenmiştir. Buna bağlı olarak, belirlenen hem olumlu hem olumsuz çevre mesajları açıklanmış ve bu mesajlar yoluyla çocuklarda oluşabilecek doğal çevre algılarına örnekler verilmiştir. Son olarak, resimli öykü kitaplarının yazarlarına, çizerlerine, yayınevlerine, bu resim kitaplarını kullanan okul öncesi öğretmenlerine, öğretmen adaylarına ve okul öncesi eğitimi alanında çalışan araştırmacılara tavsiyelerde bulunulmuştur.

Anahtar Kelimeler: resimli öykü kitabı, görsel, metin, doğa, çevre, doğal çevre mesajı, okul öncesi

\section{Are Illustrations and Texts in Picture Storybooks Innocent? - Natural Environment Messages Transmitted}

Abstract: This study critically examines the natural environment messages given in the picture storybooks and it's primarily focused on the messages given through the illustrations and the texts of the books written for preschool children. In this qualitative study where natural environment messages in the illustrations and texts were examined, case study was used. The data was collected the data by document review and examined by content analysis with the help of 3 forms, developed by the researchers.For this purpose, at the beginning of the study, books in the Children's Library located in a leading university in a capital city in Europe were scanned. After the copies were eliminated, the remaining books were evaluated, first, whether they were directly related with natural environment, and second, whether they had living organism - natural environment interaction. As a result, a total of 58 books were analyzed by the researchers. Before analyzing the data, researchers did the reliability and validity studies. At the end of the data analysis, it was found out that the writers and the illustrators were mostly giving positive natural environment messages to young readers but in a few books, maybe unconsciously, they gave negative natural environment messages to children. Accordingly, both kinds of these environmental messages were explained thoroughly and by these messages, examples of positive/negative environmental perceptions which might occur in children were given. Recommendations were given to the writers, illustrators, publishers of the picture storybooks, preschool teachers and preschool teacher candidates who are using these picture books and researchers working in the field of preschool education. preschool

Key Words: picture storybook, illustration, text, nature, environment, natural environment message, 


\section{GiRiş}

Birey, doğduğu andan itibaren yaşamını sürdürebilmek için temel becerilere ihtiyaç duyar. Bu beceriler, bireyin yaşama uyumunu kolaylaştırıcı; bilişsel, sosyal-duygusal, motor, dil gelişimi alanlarından beceriler ile özbakım becerileridir. Çocuk, bu beceriler sayesinde çevreyle etkileşim kurarak öğrenebilir ve çevresine uyum sağlayabilir. Etkileşim kurmak için çocuk, özellikle dili kullanır.

Dil gelişimi kuramcılarının öncülerindenChomsky'ye göre çocuk dille beraber doğar (Bacanlı, 2002). Chomsky dilin öğretilmesinin gerekli olmadığını ifade eder. Ayrıca fiziksel büyümenin değil, zihinsel büyümenin sonucunda genetik olarak gelişmiş zihnin, dünyayla etkileşmeye başlayacağını ve bu etkileşme yoluyla dilin daha olgunlaşacağını ifade etmektedir (Harris ve Butterworth, 2002). Bu ifadeler, dil edinimi için ortamın ve deneyimin, çocuğun doğuştan gelen süreçleri üzerinde çok az bir etkiye sahip olduğunu açıklamaktadır. Chomsky’ye göre çocuğun kalıtımla getirdiği dil öğrenme yapısı, çevresinde konuşulan dili içselleştirmesini, dilin kurallarını benimsemesini ve sonrasında uygun şekilde konuşmasını sağlar. Bu yapı sayesinde bütün çocuklar, aynı evrelerden geçerek belli bir olgunluk seviyesine geldiklerinde, tıpkı yürümeyi öğrendikleri gibi, konuşmayı da öğrenmektedirler (Kürkçüoğlu, 2010). Chomsky, çocukların beyinlerinde, bütün dillerin evrensel dilbilgisi kurallarını anlamasına olanak tanıyan dili edinme yapısına sahip olarak doğduğu düşüncesini ortaya atmıştır.

Chomsky'nin görüşlerinden farklı olarak Sosyo-Kültürel kuramcı Vygotsky ise, çocuğun çevresinin dil edinimi için önemli olduğunu ifade etmektedir. Vygotsky'ye göre, kültür ve sosyal çevre öğrenmeyi etkilediği gibi dil gelişimini, okuma yazma becerilerini ve nedenselliği de etkiler. Ayrıca dil öğrenimi, sosyal çevreden bağımsız düşünülemez. Vygotsky, çalışmalarında, çocukların birlikte zaman geçirdikleri yetişkinlerle ve/veya akranlarıyla olan etkileşimlerinin, çocukların dil gelişimine katkı sağladığını ve kültürün çocukların dil gelişiminin şekillenmesinde önemli bir yeri olduğunu ifade eder. Vygotsky, sosyal olarak başlayıp bireysel alanda devam eden dil gelişiminin özellikle geçiş ve içselleştirme aşamalarında sosyal etkileşimin önemine dikkat çekmektedir.

Vygotsky'nin “Çocuğun içinde yaşadığı sosyal ilişkilerin öğrenmenin önemli bir faktörü olduğu" sayıltısından daha geniş bir bakış açısı getiren Bronfenbrenner'e göre, okul öncesi dönemdeki çocuklar, gelişimleri gereği, bilgi edinimine öncelikli olarak kendileri ve yakın çevreleri ile başlar (Turpoğlu Çelik, 2015). Çocuğun çevresinin, eğitim ve öğretim yaşamı üzerine etkisini inceleyen Bronfenbrenner (1979), çocukların yetiştikleri çevrelerin birbirlerinden çok farklı olduğunu ve eğitim hedefleri düzenlenirken çocukların kültürel çevrelerinin farklıı̆̆ı üzerine odaklanılması gerekliliğini vurgulamaktadır. Bronfenbrenner'in savunduğu Ekolojik Gelişim Kuramı, küçük çocukların gelişimi üzerine kültürel etkilerin rolü üzerinde durmaktadır (Ross, 1989). Gelişime dayanan bu kuram, kültür ve çevrenin rolü ile daha karmaşık bir açıklamaya sahiptir. Bu kuram, genel olarak çocuk ile çevresi arasındaki kültürün ilişkisini ifade etmektedir. Kültür, toplum kuralları ve normlar öğretilirken, birçok kavramın çocuk düzeyinde verilmesi gerekliliği ortaya çıkmaktadır. Hangi konuda öğretim verilecek olursa olsun, özellikle küçük yaş gruplarındaki çocukların, dikkat çekici ve öğretilen konuyu algılamalarını kolaylaştırıcı öğretim materyalleri ile karşılaşmaları yerinde olacaktır. Bu nedenle, öğretmenlerin, kaliteli görsel uyarıcıların yer aldığı materyalleri kullanmaları, küçük çocukların konuyu öğrenmelerini kolaylaştıracaktır (Erden ve Akman, 2006). Okul öncesi dönemdeki çocukların gelişimlerini destekleyici materyaller arasında resimli öykü kitapları, çok önemli bir yer tutmaktadır (Oktay, 1998).

Çocuğun yaşamında yer alan kişilerin, başta ailesi ve öğretmenlerinin çocuğa zenginleştirilmiş deneyimler sunabilmeleri, özellikle okul öncesi dönemde daha da önem 
kazanmaktadır. Yapılan araştırmalarda, çocuğa sunulabilecek bu deneyimler arasında, resimli öykü kitapları aracılığıyla elde edilebilecek kazanımlar üzerinde önemle durulmaktadır (Bus, Van Ljzendoorn ve Pellegrini, 1995; Tür ve Turla, 1999; Adrian, Clemente ve Villanueva, 2007). Çocukların, tüm gelişim alanlarında desteklenmesi gereken en önemli yıllar olan okul öncesi dönemde, kitaplarla tanıştırımaları, onların ileriki yıllardaki gelişimleri ile eğitimlerini de yakından ilgilendirmektedir (Gönen, 2000). Çocuklar, evlerinde kitaplarla tanışmamış olsalar bile, okul öncesi eğitim kurumuna başladıklarında, yapılan etkinlikler sırasında resimli öykü kitaplarıyla etkileşim kurarak öğrenebilirler.

Çocukların dil gelişimleri açısından vazgeçilmez bir öneme sahip olan, çocuk edebiyatının başta gelen ürünlerinden olan resimli öykü kitapları, özellikle okul öncesi dönemde, okuma yazma bilmeyen çocukların resimler yoluyla bilgi edinimleri kolaylaşmaktadır (Soydan, 2014). Çocuklara resimli öykü kitapları okunduğunda, çocukların, kitapların yazııı dili aracılığıyla sözel, resimleri aracılığıyla da görsel bilgiye kolayca ulaşmaları sağlanabilmektedir. Burada bahsedilen sözel bilgi, yazarlar tarafından okuyucuya kitaplar yoluyla aktarılan bilgidir ve okunan ya da dinlenen metin içine yerleştirilmiştir. Görsel bilgi ise, resimler aracılığıyla okuyucuya aktarılan ve kitaplarda yer alan resimlerin içine gizlenmiş bilgiyi ifade etmektedir (Senemoğlu, 2007). Bu şekilde, resimli öykü kitaplarında metin ile görselin birleşiminden farklı bir sanat ve estetik yapı ortaya çıkmaktadır (Taşdelen, 2016).

Günümüzde basılan resimli öykü kitaplarında, metinler ve görseller arasında yeni bir denge söz konusudur ve bu denge görseller tarafında yoğunlaşmaktadır. Artık görsellerin ve metinlerin sahip olduğu kendine özgü anlatımının ötesinde bir anlatım dilinin olduğu inanışı yaygınlaşmıştır. Görseller, metinde geçen olayı ortaya koymanın ötesinde, metnin planı veya ana düşüncesiyle bütünleşen zengin ayrıntılar içermektedir (Kara, 2012) ve bu nedenle resimli öykü kitaplarındaki görseller, küçük çocukların daha çok bilgi edinmelerine yardımcı olabilir.

Resimli öykü kitaplarında yer alan metinler ve görsellerin yanı sıra, öykünün kurgusunda yer alan karakterler de çocukların yaşamlarında önemli unsurlardır. Çocuklar, kitaplardaki karakterlerin, özellikle de kahramanların davranışlarından etkilenerek öğrenirler. Bu öğrenmeler, olumlu ya da istem dışı da olsa, olumsuz olabilir. Konuyla ilgili olarak, alanın önde gelen araştırmacılarından Sever (2003, s. 64-65), çocuk kitaplarındaki kahramanlarla okuyucular arasındaki güçlü ilişkiyi şu cümlelerle ifade etmektedir: "Çocuk okuyucu, kahramanlar aracılığıyla insanların başından geçebilecek olayları tanır. Sorunlar karşısında takınacağı tavır ya da geliştirebileceği davranışlara ilişkin ipuçları edinir." Bu nedenle, resimli öykü kitaplarındaki karakterlerin, çocuklara, her konuda olduğu gibi "çevre" konusunda da olumlu davranışlar sergileyecek şekilde dikkatle tanıtılması gerekmektedir. Küçük çocukların kitaplarda gördükleri karakterleri örnek almaları ve onlarla özdeşim kurmaları nedeniyle (Bulut ve Kuşdemir, 2013), kitaplardaki karakterlerin çocukların kişilik yapılarının gelişiminde önemli roller üstlendiği yadsınamaz bir gerçektir (Mardi, 2006). Gökçe ve Sis (2011)'e göre ise çocukların kitaplardaki karakterlerle kurdukları ilişkileri yaşamları boyu onları etkileyebilir.

Hayvan veya bitki karakterlerin insan karakterlerin yerlerine konularak insan davranışları sergilemeleri (insanbiçimlik-antropomorfizm), edebi eserlerde uzun yıllardan beri kullanılmaktadır. İnsanbiçimliğin kullanımı, çocuk edebiyatını, didaktik türdeki edebi eserlerden ayırıcı özelliktedir. Bu durum, başta resimli öykü kitapları olmak üzere, çocuk edebiyatı eserlerini "çocuğa özgü" kılmaktadır. Yakın çevrelerinde gördükleri hayvanlar ve bitkilerin resimli öykü kitaplarında kullanımı, okul öncesi dönemdeki çocuklar ile doğa arasında oldukça esnek ve duygudaşlık ile yüklü bir alan oluşumunda etkili olmaktadır. Kitaplardaki resimlerin, özellikle hayvan karakterlerden oluşması, çocuğun dünyasında yeni ve farklı bir duyarlılı̆ın kapılarını aralar. Başka bir ifadeyle, hayvan karakterlerin olduğu kitaplarla etkileşim içinde olan çocuğun duygusal ve bilişsel yetilerinin gelişiminde bu kitaplar, etkin birer araç olabilir (Uğurlu, 
2013). Sever (2003)'in belirttiği gibi, çocuk kitaplarındaki görsellerin çocuğun gelişim sürecine katkılarından biri de çocuğa, yaşadığı çevreye daha duyarlı bakmayı öğretmesidir. Bu nedenle, bahsi geçen resimli öykü kitaplarında, yaşadığımız dünyayı sevmeyi, onun güzelliklerinden yararlanmayı ve yanlış giden durumlarda sorunları çözmeye yönelik davranışlara model olmayı gösteren metin ve görsellerin yer alması gerekmektedir (Lüle, 2007). Aynı zamanda çocuk kitaplarının, özellikle de bu kitaplardaki görsellerin, çevre gibi küresel konuların öğretiminde (Muthukrishnan ve Kelly, 2016) ve çocuklarda çevre duyarlılığının gelişiminde destek materyali olarak kullanılması yerinde olacaktır.

Bu noktada, çevrenin tanımının yapılması gerekliliği ortaya çıkmaktadır. Genel olarak çevre, insan aktivitelerini ve canlıları, şimdi ya da belli bir süre sonra, doğrudan veya dolaylı şekilde etkileyebilecek, fiziksel, kimyasal, biyolojik ve toplumsal faktörlerin tamamıdır (Hamamcı ve Keleş, 1998). Çevreyle etkileşim, olumlu ya da olumsuz olabilmekte ve bu etkileşimin sonuçları süreç içerisinde anlaşılmaktadır (Kuzu, 2007). İnsanların çevreyle olumsuz etkileşimi, çevreyi ve o çevrede bulunan tüm canlıları olumsuz etkileyebilir. Örneğin; çevrenin kirlenmesi, uzun vadede iklim değişikliklerine ve birçok canlı neslinin yok olmasına neden olabilir. Bilinçsiz davranışlarıyla bu kirlenmeye sebep olan insan da, diğer canlılar gibi bu olaydan olumsuz yönde etkilenebilir. Günümüzde, kirliliğin yüksek düzeylerde artışıla insanlar, kirliliğin durdurulması konusunda daha duyarlı olmaya başlamışlardır. Fakat kirliliğin önlenmesiyle ilgili çalışmalar halen yeterli değildir. Toplumun birer parçası olarak, çocukların da çevre kirliliği başta olmak üzere, bütün çevresel ve toplumsal sorunların çözümünde yaşlarına uygun olarak katkı sağlamaları gerekmektedir. Bu yüzden, çevre sorunlarıyla ilgili eğitimin erken yaşlardan itibaren okullarda sistematik ve düzenli bir şekilde verilmesi gerekmektedir (Morgil, Ural, Erdem, Oskay ve Yılmaz, 2005).

Bronfenbrenner (1979)'in araştırmalarında ifade ettiği gibi, küçük çocuklarla çalışırken, ilk olarak çocuğun yakın çevresiyle ilgili bilgilerden başlayarak öğretim yapılmalıdır. Küçük çocuğun çevresini, yaşadığı ortam; yani odası, evi, aile üyeleri, komşuları, park, bahçe, sokak vb. oluşturmaktadır. Çocuğun yaşamının ilk yıllarında, çevresi hakkında öğreneceği bilgiler, çevreyi tanıma ve çevreyi koruma olarak ikiye ayrılmalıdır. Çocuk, çevresiyle tanışırken verilecek en uygun mesaj, çevresindeki nesnelerin ve kişilerin, yani ortamın kendisine ait olduğu ve onun da bu ortamın bir parçası olduğudur. "Odan", "okulumuz", "ailemiz", "apartmanımız" gibi benimseme ifadeleri kullanıldığında, çocukta çevreye ait olma duygusu gelişecektir. Sonraki evrede ise ait olmanın yanında, sorumluluk duygusunun eklenmesi söz konusudur. Çocuk, küçük yaşlarda çevresine karşı sorumluluk hissederse, çocukta çevreyi koruma davranışı gelişebilir. Küçük yaştaki çocuklarda çevreyi koruma davranışları; başta çocuğun odasındaki oyuncaklarını toplaması, evini kirletmemesi, anaokulunda bir etkinlikten sonra malzemeleri toplayıp yerlerine yerleştirmesi gibi davranışlardır (Bozkurt, 2009). Çocuğa bu davranışların öğretilmesi, rol model olmayla gerçekleşebilir, çünkü küçük çocuk, gözlemler ve gözlemlediğini taklit eder. Yakın çevresi ile ilgili sorumluluk sahibi olarak gelişen çocuk, ileride toplumsal ve küresel çevre sorunlarına da duyarlı olabilir. Bahsi geçen bu eğitim "çevre eğitimi" olarak adlandırılır. Şimşekli (2004), çevre eğitiminin en genel anlamda, doğayı ve doğal kaynakları korumaya yönelik olduğunu, çevre eğitiminin yalnızca bilgi vermeye yönelik değil, davranışları da olumlu yönde değiştirecek şekilde olması gerektiğini ifade etmektedir. Çevre eğitiminin başlıca hedefinin olumlu ve kalıcı davranış değişikliği ile bireylerin çevre sorunlarının çözümünde etkin katılımını sağlamak olduğu savunulmaktadır.

Alanyazında yer alan çalışmalar, okul öncesi dönemde verilen çevre eğitiminin çeşitli yararları olduğunu ortaya koymaktadır. Örneğin; çocukların bütünsel (fiziksel, bilişsel, sosyalduygusal ve dil) gelişimleri ile gerekli becerileri (özbakım gibi) edinimleriyle ilgili olabilir (Wilson, 1994). Bu sebeple, çevre eğitimi, erken dönemlerden itibaren verilmeye başlanmalıdır. 
Dolayısıyla, çevre eğitiminin uygulayıcısı olan okul öncesi öğretmenlerine önemli roller düşmektedir. Okul öncesi öğretmenlerinin öncelikle çocukların ilgi ve ihtiyaçlarına uygun, yaparak yaşayarak öğrenebilecekleri aktif öğrenme ortamları oluşturmaları gerekmektedir. (Wilson, 2008).

Araştırmacılar, çevre konularının çocuklara beş amaç çerçevesinde öğretilebileceği konusunda hemfikirdirler. Bu beş amaççevre konularında farkındalık yaratma,bilgi verme, tutum geliştirme, beceri kazandırmave katılım göstermeolarak belirtilmiştir (Braus ve Wood, 1993Akt. Haktanır, 2007).

Günümüzde, sonraki nesillerin daha sağlıklı ve güvenli bir çevrede yaşamaları için çevreye duyarlı bireyler yetiştirmek, bir gereklilik durumuna gelmiştir (Şahin, Cerrah, Saka ve Şahin, 2004, s. 114). Kuzey Amerika Çevre Eğitim Birliği, çocuklara çevreyi öğretmek için verilmesi gereken eğitimin basamaklarını şu şekilde belirtmektedir (Ayvaz, 1998, s. 32):

(1) Çevreye karşı duyarlılık ve ilgi

(2) Doğal sistemin işleyişiyle ilgili bilgilendirme

(3) Çevreye karşı olumlu değer yargısı

(4) Çevreye aktif katılım ve katkıda bulunma becerisi

(5) Çevre sorunlarını engelleme ve sorunların çözülmesinde deneyim

Güner ve Kesicioğlu (2012)'nun verilen çevre eğitiminin yararlı olup olmadığının belirlenmesi amacıyla gerçekleştirdikleri araştırmalarında, okul öncesi dönemden başlayarak çocukların çevre eğitiminin farklılaştırılmış öğretim ile verilmesi gerekliliği belirlenmiş ve çevre eğitiminde farklı yöntemlerin kullanılmasının çevre konusunda duyarlılı̆ı artıracağı ortaya konmuştur. Bu kapsamda, okul öncesi eğitim kurumlarında yapılan Türkçe, oyun ve dramatizasyon gibi etkinlikler aracılığıyla çocuklara çevre ile ilgili bilgiler verilebilir (ileri, 1998). Bahsi geçen okul öncesi eğitim etkinlikleri çeşitli materyaller kullanılarak zenginleştirilebilir ve bu materyaller çocukların ilgilerini, öğrenilmesi istenen konuya çekmekte yardımcı olabilir. Bu materyaller arasında dikkati çeken resimli öykü kitaplarının en önemli amaçlarından biri, çocuğa insanı, doğayı ve yaşamayı sevdirmektir (Çılgın Sınar, 2007; Çakır illhan 1994). Çocuğun küçük yaşta bu sevgiyi edinmesi, bu sevginin kalıcı olma olasılı̆ıını arttıracaktır (Çabuk, 2000). Benzer şekilde, resimli öykü kitapları, çocukların çevrelerine karşı geliştirdikleri merak duygusunu tetikleyerek onlarda doğayı keşfetme isteği uyandııı ve çocukların hayal dünyasına katkı sağlayacak anlatımlara ve örneklere yer verir (Dinçer, 1999). Bu durumda, çevre konularını içeren resimli öykü kitaplarının okul öncesi eğitimde kullanılmasının önemi ortaya çıkmaktadır. Okul öncesi eğitimde resimli öykü kitapları yoluyla verilen mesajların çocukta bırakacağı etkinin önemli olması nedeniyle, verilen mesajların, yazarlar ve resimleyenler tarafından titizlikle belirlenmeleri gerekmektedir. Öğretmenler, sınıflarında okudukları kitaplar yoluyla olumlu çevre mesajları vererek çocukların sürdürülebilirlik, doğayla bütünleşme, yaşanılan yer bilinci (Orr, 1990) ve çevrenin önemi konularında bilgiler edilmelerini destekleyebilirler.

1970-1993 yılları arasında Türkiye'de basılmış olan resimli öykü kitaplarının konu sıralaması incelendiğinde, çevre konusunun en çok işlenen ikinci konu olduğu saptanmıştır (Uzmen 1993). 90'lardan sonra çevreyi konu alan kitapların sayısı giderek artmıştır. Buna rağmen, bu kitapların niteliğini incelendiği araştırmalar, alanyazında yeterli sayıda yer almamaktadır. Küçük yaştan itibaren çevre ve çevre konuları konusunda bilgili ve duyarlı olarak yetişen çocukların gelecekte bilinçli davranışlar sergiyeleyecekleri düşünüldüğünde, okul öncesi eğitim kurumlarında sıklıkla kullanılan resimli öykü kitaplarının sayısının ve niteliğinin arttırılması büyük önem taşımaktadır (Kuzu, 2007). Bu araştırma kapsamında, ülkemizde, özellikle okul öncesi dönem çocuklarına yönelik olarak geliştirilen resimli öykü kitapları yoluyla 
çevre konularının öğretilmesi konusunda yapılan araştırmalar (Alan, 2015; Uğurlu, 2013; Yılmaz ve Özen Uyar, 2016) incelenmiş, bahsi geçen araştırmaların sayılarının yetersiz olduğu, özellikle,konuyla ilgili kitapların derinlemesine incelendiği nitel araştırmalarınsınırlı olduğu, yapılan araştırmaların bir kısmının da ilkokul veya daha üst eğitim düzeylerindeki çocuklara yönelik hazırlanan kitapları konu alan çalışmalar olduğu (Aydın ve Sevinç, 2016; Aslan, 2015; Canbay ve Edizer, 2012) belirlenmiştir. Bu nedenle, bu nitel araştırmada, bir üniversitenin çocuk kütüphanesindeki 3-6 yaş grubu çocuklara yönelik hazırlanan resimli öykü kitaplarında yer alan görsellerin ve metinlerin okuyuculara verdiği olumlu/olumsuz doğal çevre mesajlarının incelenmesi amaçlanmıştır. Bu amaç doğrultusunda şu sorulara cevap aranmıştır:

1. Okul öncesi dönem çocuklarına yönelik hazırlanan resimli öykü kitapları doğrudan/dolaylı doğal çevre konusuna değinmekte midir?

2. Okul öncesi dönem çocuklarına yönelik hazırlanan resimli öykü kitaplarında hangi canlı (insan/hayvan/bitki)-doğal çevre etkileşimi yer almaktadır?

3. Okul öncesi dönem çocuklarına yönelik hazırlanan resimli öykü kitaplarındaki görseller ve metinler canlı (insan/hayvan/bitki)-doğal çevre etkileşimine göre hangi olumlu/olumsuz doğal çevre mesajlarını içermektedir?

4. Okul öncesi dönem çocuklarına yönelik hazırlanan resimli öykü kitaplarındaki görsellerde ve metinlerde verilenolumlu/olumsuz doğal çevre mesajlarının çocuklarda oluşturabileceği doğal çevre algıları nelerdir?

\section{YÖNTEM}

3-6 yaş grubu çocuklarına yönelik hazırlanan resimli öykü kitaplarının olumlu doğal çevre mesajı verip vermeme durumunun incelenmesi amacıyla yapılan bu çalışmada araştırmanın modeli, araştırma grubu, veri toplama yöntemleri, veri toplama araçları, verilerin analizi ve geçerlik-güvenirlik çalışmaları ile ilgili bilgiler aşağıda verilmiştir:

\subsection{Araştırmanın Modeli}

Bu araştırma; nitel araştırma yöntemlerinden biri olan durum çalışması, diğer adıyla örnek olay incelemesi(case study) modeli ile gerçekleştirilmiştir. Nitel araştırmalar, bir konu üzerine araştırma yapılırken, konunun "ne kadar" olduğunu öğrenmek yerine, daha geniş bir bakış açısı elde etmek amacıyla, belli bir niteliği üzerine odaklanan araştırmalardır (Büyüköztürk, Çakmak, Akgün, Karadeniz ve Demirel, 2016). Durum çalışması ise, devam eden güncel bir olayı derinlemesine incelemekle ilgilidir (Yin, 2013) ve gözlem, görüşme veya doküman toplama ile elde edilen verilerin boylamsal ve detaylı incelenmesine olanak sağlar (Glesne, 2012). Kısaca; durum araştırması, belirsiz ya da değişken olan bir durum ve onun içinde bulunduğu bağlam açık olmadığında, nedenleri, düşünce ve tutumları gibi boyutları ortaya çıkarmak amacıyla gerçekleştirilir (Creswell, 2016).

\subsection{Araştırma Grubu}

Araştırmada, amaçlı örnekleme (purposeful sampling) yöntemlerinden, ölçüt örneklemeyöntemi kullanılmıştır. Amaçlı örneklemede, evreni temsil eden grupları belirlemek amacıyla özel bilgilere göre seçim yapılır. Belirli tipik özellikleri sergileyen örneklem, alan araştırması yapıldıktan sonra seçilir (Berg \& Lune, 2015). Amaçlı örnekleme, çalışmanın amacına bağlı olarak bilgi açısından zengin durumların seçilerek derinlemesine araştırılmasına olanak sağlar (Büyüköztürk vd., 2016). Bu araştırmada, bir üniversitenin ilgili fakültesinde yer alan çocuk kütüphanesindeki 8077 adet kitap arasından, belirlenen ölçütleri sağlayan kitaplar ile analizler gerçekleştirilmiştir. Belirlenen tüm ölçütler konusunda üç araştırmacının da aynı 
görüşte olmasına dikkat edilmiştir. Kütüphanede yer alan kitapların hangilerinin araştırma kapsamında incelendiğini belirleyen ölçütler aşağıda belirtilmektedir:

1. Kitapların 3-6 yaş grubu çocuklarına uygun olması,

2. Kitapların resimli öykü kitabı olması,

3. Kitaplarda, doğrudan/dolaylı olarak canlı (insan/hayvan/bitki)-doğal çevre etkileşiminin yer alması,

4. Kitapların olumlu/olumsuz doğal çevre mesajı verdiğidir.

Ölçütler belirlendikten sonra, çocuk kütüphanesindeki 8077 adet kitap arasından, 3-6 yaş grubu çocuklarına yönelik olan resimli öykü kitapları $(n=954)$ belirlenmiştir. 954 adet kitabın 2. ve 3. kopyaları çıkarıldıktan sonra $(n=671)$, araştırmacılar tarafından etkileşimli olarak tüm kitaplar taranmış, kitaplarda doğrudan/dolaylı olarak canlı (insan/hayvan/bitki)-doğal çevre etkileşiminin yer alma durumları tablolaştırılıp, canlı-doğal çevre mesajı içerdiği düşünülen 79 kitap analiz için ayrılmıştır. 79 resimli öykü kitabı, araştırmacılar arasında çaprazlanarak aynı kapsamda tüm araştırmacılar tarafından bireysel olarak analiz edilmiştir. Üç araştırmacının da olumlu/olumsuz doğal çevre mesajı verdiği konusunda hemfikir olduğu 58 resimli öykü kitabı ile analizler gerçekleştirilmiştir.

Fakültenin çocuk kütüphanesinde belirlenen ölçütleri sağlayarak analize alınan 58 resimli öykü kitabının demografik bilgileri (kitaplar, yayınevleri ve yayın yılları) Tablo 1'de yer almaktadır. 
Tablo. 1

Araştırma Grubunun Demografik Bilgileri (Kitaplar yayın yılına göre sıralanmıştır.)

\begin{tabular}{|c|c|c|c|c|}
\hline $\begin{array}{l}\text { Kitabın } \\
\text { Kodu }\end{array}$ & Yayınevi & Yayın Yılı & Konu & Türkçe/Çeviri \\
\hline K1 & Epsilon & Bilinmiyor & Çevre & Bilinmiyor \\
\hline K2 & Esin & Bilinmiyor & Güç illişkisi & Bilinmiyor \\
\hline K3 & Esin & Bilinmiyor & İç Güzelliği & Bilinmiyor \\
\hline K4 & Kök & Bilinmiyor & Sorumluluk & Türkçe \\
\hline K5 & Hobi & Bilinmiyor & Değerler & Türkçe \\
\hline K6 & Hobi & Bilinmiyor & Değerler & Türkçe \\
\hline K7 & Hobi & Bilinmiyor & Çevre & Türkçe \\
\hline K8 & Hobi & Bilinmiyor & Empati & Türkçe \\
\hline K9 & Kitapark & Bilinmiyor & Bilinçsizlik & Türkçe \\
\hline K10 & Altın Kitaplar & Bilinmiyor & Çevre & Çeviri \\
\hline K11 & Umut Kaya & Bilinmiyor & Çevre & Türkçe \\
\hline K12 & YA-PA & Bilinmiyor & Çevre & Türkçe \\
\hline K13 & YA-PA & 1991 & Şehir Yaşamı & Türkçe \\
\hline K14 & Mavibulut & 1995 & Çevre & Türkçe \\
\hline K15 & Uçan Balık & 1996 & Çevre & Türkçe \\
\hline K16 & Uçan Balık & 1996 & Çevre & Türkçe \\
\hline K17 & Uçan Balık & 1996 & Farklılıklara Saygı & Türkçe \\
\hline K18 & Altın Kitaplar & 1996 & Çevre & Çeviri \\
\hline K19 & Altın Kitaplar & 1996 & Çevre & Çeviri \\
\hline K20 & Uçan Balık & 1997 & Çevre & Türkçe \\
\hline K21 & Uçan Balık & 1997 & Büyüklere Saygı & Türkçe \\
\hline K22 & Uçan Balık & 1997 & Çevre & Türkçe \\
\hline K23 & Uçan Balık & 1997 & Yardımseverlik & Türkçe \\
\hline K24 & Uçan Balık & 1997 & Çevre & Türkçe \\
\hline K25 & Uçan Balık & 1997 & Çevre & Türkçe \\
\hline K26 & Uçan Balık & 1998 & Çevre & Türkçe \\
\hline K27 & Uçan Balık & 1998 & Çevre & Türkçe \\
\hline K28 & Uçan Balık & 1998 & Çevre & Türkçe \\
\hline K29 & Uçan Balık & 1998 & Yardımseverlik & Türkçe \\
\hline K30 & Uçan Balık & 1998 & Çevre & Türkçe \\
\hline K31 & Altın Kitaplar & 1998 & $\begin{array}{l}\text { Farklı Ortamlarda } \\
\text { Yaşam }\end{array}$ & Türkçe \\
\hline K32 & Altın Kitaplar & 1998 & Çevre & Türkçe \\
\hline K33 & Altın Kitaplar & 1998 & Çevre & Çeviri \\
\hline
\end{tabular}

\begin{tabular}{|c|c|c|c|c|}
\hline $\begin{array}{l}\text { Kitabın } \\
\text { Kodu }\end{array}$ & Yayınevi & Yayın Yılı & Konu & Türkçe/Çeviri \\
\hline K34 & Kök & 1998 & Çevre & Türkçe \\
\hline K35 & Altın Kitaplar & 1999 & $\begin{array}{l}\text { Farklı Ortamlarda } \\
\text { Yaşam }\end{array}$ & Türkçe \\
\hline K36 & AÇEV & 1999 & $\begin{array}{l}\text { Farklı Ortamlarda } \\
\text { Yaşam }\end{array}$ & Türkçe \\
\hline K37 & Altın Kitaplar & 1999 & $\begin{array}{l}\text { Farklı Ortamlarda } \\
\text { Yaşam }\end{array}$ & Çeviri \\
\hline K38 & Altın Kitaplar & 1999 & Çevre & Çeviri \\
\hline K39 & Epsilon & 1999 & Çevre & Türkçe \\
\hline K40 & Dörtel & 1999 & Yardımseverlik & Türkçe \\
\hline K41 & YA-PA & 2000 & Ateşin İşlevi & Çeviri \\
\hline K42 & Altın Kitaplar & 2000 & Merak & Türkçe \\
\hline K43 & ATP & 2002 & Çevre & Bilinmiyor \\
\hline K44 & Altın Kitaplar & 2002 & Çevre & Türkçe \\
\hline K45 & Altın Kitaplar & 2002 & Güç iliş̧kisi & Çeviri \\
\hline K46 & Altın Kitaplar & 2003 & Güç iliş̧kisi & Bilinmiyor \\
\hline K47 & Kök & 2003 & Çevre & Türkçe \\
\hline K48 & Kök & 2003 & Çevre & Türkçe \\
\hline K49 & Kök & 2003 & Çevre & Türkçe \\
\hline K50 & Akçağ & 2003 & Çevre & Türkçe \\
\hline K51 & Akçağ & 2005 & Çevre & Türkçe \\
\hline K52 & Uçan Balık & 2006 & Çevre & Türkçe \\
\hline K53 & Can Çocuk & 2008 & Çevre & Türkçe \\
\hline K54 & TUDEM & 2008 & Çevre & Türkçe \\
\hline K55 & Can Çocuk & 2008 & Çevre & Türkçe \\
\hline K56 & Günışığı & 2009 & Çevre & Türkçe \\
\hline K57 & TIMAŞ & 2011 & $\begin{array}{l}\text { Farklı Ortamlarda } \\
\text { Yaşam }\end{array}$ & Çeviri \\
\hline K58 & Altın Kitaplar & 2013 & Çevre & Türkçe \\
\hline
\end{tabular}


Tablo 1 incelendiğinde, değerlendirmeye alınan 58 resimli öykü kitabının çoğunluğunun Uçan Balık Yayınları ( $n=15)$ ve Altın Kitaplar Yayınları $(n=14)^{\prime}$ ndan olduğu görülmüştür. En az kitap ise 1'er kitap ile AÇEV, ATP, Dörtel, Günışığı, Kitapark, Mavi Bulut, TiMAŞ, TUDEM ve Umut Kaya Yayınları'ndan çıkmıştır. Kitaplar, yayın yıllarına göre incelendiğinde, 12 kitabın yayın yılııın belirtilmediği görülmektedir. En çok 1998 yılına ait kitabın bulunduğu (n=9), 1997'de ise 6 kitabın yayınlandığı, 1991, 1995, 2005, 2006, 2009, 2011, 2013'de ise 1'er kitabın yayınlandığı belirlenmiştir. Kitapların çoğunluğunun $(n=36)$ konusunun çevre ile ilgili olduğu, kalanının ise $(n=22)$ çevre ile ilgili olmadığı bulunmuştur. Bu konuların en çok "Farklı Ortamlarda Yaşam" (n=5), "Yardımseverlik" (n=3) ve "Güç ilişkisi" ( $n=3)$ olduğu tespit edilmiştir. Kitapların çoğunun $(n=42)$ orijinal dilinin Türkçe olduğu, bir kısmının ( $n=9)$ başka dillerden Türkçe'ye çevrildiği, kalanının $(n=7)$ ise yazarının belirtilmemiş olması nedeniyle bilinmediği tespit edilmiştir.

\subsection{Verilerin Toplanması}

Araştırmada, veriler, nitel veri toplama yöntemlerinden doküman incelemesi yöntemi ile toplanmıştır. Nitel dokümanlar, araştırılması amaçlanan olgu ya da olaylar ile ilgili bilgileri içeren yazılı materyallerdir (Yıldırım ve Şimşek, 2003). Bu araştırmada, bir üniversitenin ilgili fakültesinde yer alan çocuk kütüphanesindeki 3-6 yaş grubu çocuklara yönelik hazırlanan, içinde canlı (insan/bitki/hayvan)doğal çevre etkileşimi ve olumlu/olumsuz doğal çevre mesajları yer alan resimli öykü kitapları, bu araştırmanın nitel dokümanları olarak belirlenmiştir.

\subsection{Veri Toplama Araçları}

Araştırma kapsamında, araştırmacılar tarafından geliştirilen 3 form ile veriler toplanmıştır:

(1) Doküman incelemesi amacıyla araştırmacılar tarafından ilgili alanyazın taramasından sonra geliştirilen "Kitap Sınıflama Formu" kullanılarak canlı-doğal çevre etkileşimi yer alan kitaplar belirlenmiştir.Kitap Sınıflama Formu kullanılarakkitabın temasının "doğal çevre" olup olmama durumu ile kitapta "insan-doğal çevre etkileşimi", "hayvan-doğal çevre etkileşimi" ve "bitki-doğal çevre etkileşimi" olup olmama durumu belirlenmiştir. Canlı-doğal çevre etkileşimi yer alan kitapların isimleri,ilgili bölümün altına yazıımıştır. Eş zamanlı olarak kitapların 2. ve 3. kopyalarının çıkarılması işlemi de bu form üzerinde gerçekleştirilmiştir.

(2) Belirlenen kitaplar, "Kitap Künye Bilgisi Formu"na kaydedilmiştir. Kitap Künye Bilgisi Formu'nda, kitabın adı, yayın yılı ve yayınevi bilgileri yer almıştır.

(3) "Doğal Çevre Mesajı Formu", resimli öykü kitaplarında yer alan olumlu/olumsuz doğal çevre mesajlarının verilme durumunu belirlemek amacıyla kullanılmıştır. Verilen canlı (insan/hayvan/bitki)-doğal çevre etkileşimini belirleme işleminden sonra araştırmacılar tarafından geliştirilen "Doğal Çevre Mesajı Formu" kullanılarakkitaplarda yer alan olumlu/olumsuz doğal çevre mesajlarının görseller ve metinlerde verilme biçimi incelenmiştir. Forma, araştırmacıların en çarpıcı olduğunu düşündükleri örnek metinler ve görseller kaydedilmiştir.

\subsection{Verilerin Analizi}

Doküman incelemesi yoluyla resimli öykü kitaplarından elde edilen veriler, içerik analizi yöntemi ile çözümlenmiştir. İçerik analizi, toplanan verileri açıklayabilecek ilişkilere ve kavramlara ulaşmak amacıyla yapılmaktadır. Betimsel analizin aksine, içerik analizinde özetlenen veriler, içerik analizinde daha derin bir işlemden geçirilir. Betimsel analiz ile fark edilmeyen kavramlar, bu analizle keşfedilir (Yıldıım ve Şimşek, 2003). İçerik analizi, metinler içinde yer alan kavramların varlığını belirlemeye yönelik yapılırken, görsellerin incelenmesinde de kullanılabilir (Büyüköztürk vd., 2016). Bu araştırmada, resimli öykü kitaplarındaki hem metinlerin hem de görsellerin verdiği mesajların incelenmesi yapıldığından, içerik analizi yöntemi, araştırmada elde edilen verilerin analizi için en uygun yöntem olarak belirlenmiştir.

Nitel araştırmaların veri analizinde bazı genel adımlar söz konusudur. Bunlar; toplanan belgelerin düzenlenmesi, kopyalarının çıkarılması ve kodlanıp özetlenerek yorumlanmasıdır. Durum 
araştırmalarına özgü veri analizinde ise; kategorik birleştirme, doğrudan yorumlama, modelleri çizme ve doğal genellemedir. Kategorik birleştirmede veriler, kodlanarak anlamların çıkacağı örnekler toplandığından (Büyüköztürk vd., 2016), bu araştırmada, kategorik birleştirme yöntemi ile analizler gerçekleştirilmiştir. Araştırmada, resimli öykü kitaplarındaki metinlerle görsellerin incelenmesi, verilen mesajların temalandırılması ve benzer mesajların ortak temalarda birleştirilmesi biçiminde yapılmıştır.

\subsection{Geçerlik ve Güvenirlik Çalışmaları}

$\mathrm{Bu}$ nitel araştırmada, araştırmacılar tarafından konunun olabildiğince tarafsız olarak değerlendirilebilmesi amacıyla öncelikle gerekli geçerlik çalışmaları yapılmıştır. Merriam (1988)'a göre, geçerlik, nitel araştırmalarda toplanan verilerin gerçekliğini yansıtır. Geçerliğin sağlanması amacıyla, bu araştırmada, meslektaş teyidi (Yıldırım ve şimşek, 2008) yöntemi kullanılmıştır. Araştırmada, geçerliği belirlemek amacıyla, verilerin iç ve dış geçerlik analizleri gerçekleştirilmiştir.

Iç geçerlik, araştırmacının belirlediği olgulara ilişkin yorumlarının gerçeği yansıtma durumunu belirlemek (Bütün ve Demir, 2013) amacıyla aşağıdaki basamaklar gerçekleştirilmiştir:

1. Araştırma bulgularının kendi içinde tutarlı ve anlamlı olabilmesi amacıyla öncelikle iki kitap rastgele seçilerek üç araştırmacı tarafından, canlı-doğal çevre etkileşimi olma durumu ve etkileşimin kitap içinde hangi metin ve görselde yer aldığı ayrı ayrı analiz edilmiştir. Meslektaş teyidi amacıyla gerçekleştirilen bu aşamada, hemfikir olunan 79 kitap,üç araştırmacı arasında paylaştırılarak, hem görsellerin hem de metinlerin canlı (insan/hayvan/bitki)-doğal çevre etkileşimi aracılığıylaolumlu/ olumsuz doğal çevre mesajıverme durumları detaylı olarak incelenmiştir.

2. Bulguları teyit etme amacıyla 79 adet resimli öykü kitabı, araştırmacılar arasında çaprazlanarak aynı kapsamda tüm araştırmacılar tarafından ayrı ayrı analiz edilmiştir. Üç araştırmacının da canlı (insan/hayvan/bitki)-doğal çevre etkileşiminin yer aldığını ve olumlu/olumsuz doğal çevre mesajı verdiğini öne sürdüğü görsel ve metinleri diğer iki araştırmacıya sunmuştur.

3. Açık olmayan olguların belirlenmesi amacıyla, her araştırmacının sunduğu kanıtların yer aldığı kitaplar, diğer iki araştırmacı tarafından onaylanmıştır. Belirsizlik içeren ifadelerin yer aldığı kitapların yeniden incelenmesi önerisinde bulunulmuştur. Bu doğrultuda, yapılan incelemelerle elde edilen verilerin açıklığı, üç araştırmacı tarafından onaylanmıştır. Böylece 58 kitap ile analizlere devam edilmiştir.

4. Araştırmacılar, olguları yeniden değerlendirerek, okuyucu için olguların açık ve net bir şekilde ifade edildiğinde hemfikir olmuşlardır ve gerçekçiliğini onaylamışlardır.

Dış geçerlik analizi, araştırma sonuçlarının genellenebilirliği ile ilişkilidir ve doğrudan genellenemeyeceği bazı durumlarda dolaylı olarak yapılabilir (Maxwell, 1992). Araştırma sorularının ilgili kuramlarla tutarlı olup olmadığı, bulguların benzer ortamlarda test edilebilirliği gibi soruların yanıtlarının verilmesi güç olabileceğinden, genellikle araştırmacıların okuyucuları, çalışmanın tüm aşamaları hakkında ayrıntılı olarak bilgilendirmesi gerekmektedir. Bu nedenle, bu araştırmada, dış geçerlik amacıyla, tüm aşamalar ayrıntılı olarak belirtilmiştir. Araştırmacılar, aşağıdaki ifadeleri açıklayarak genellenebilirliği test etmişlerdir. Bu amaçla üç araştırmacı tarafından;

- araştırma örnekleminin süreçlerinin başka örneklemlerle karşılaştırma yapabilecek düzeyde ayrıntılı olarak tanımlandığına,

- örneklemin genellemeye izin verecek şekilde çeşitlenmiş olduğuna,

- araştırmanın sonuçlarının araştırma soruları ile ilgili kuramlarla tutarlı olduğuna karar verilmiştir.

Güvenirlik, araştırma sonuçlarının tekrar edilebilirliği ile ilintilidir. Çalışma, aynı koşullarda ikinci kez yürütülürse, aynı sonuçlara ulaşıp ulaşımayacağının belirlenmesi amacıyla güvenirlik gerçekleştirilir. Bunun için üç güvenirlik ölçütü söz konusudur (Karataş, 2015). Bunlar, 
1. Zamana göre değişmezlik:Bu araştırma kapsamında, resimli öykü kitapları, incelendikten dört ay sonra, araştırmacıların birbirlerine verdikleri öneriler doğrultusunda, ikinci kez analiz edilmiş ve aynı sonuçlar elde edilmiştir.

2. Bağımsız gözlemciler arası uyum: Araştırmada, resimli öykü kitapları bağımsız olarak tek tek analiz edildikten sonra, üç araştırmacı arasında hem el değiştirerek hem de üç araştırmacı bir araya gelerek tekrar tekrar incelenmiş ve aynı bulgulara ulaşılmıştır.

3. İç tutarlık:Araştırma süresince, üç araştırmacının da olguları aynı bakış açısıyla değerlendirdiği ve mesajlara benzer temaların altında yer verdiği görülmüştür.

Özetle bu araştırmada geçerlik ve güvenirliğin sağlanması;

- Örneklemin yeterli büyüklükte seçilmesiyle,

- Birden çok araştırmacıyla konunun ele alınmasıyla,

- Daha çok kaynak ve görüşe başvurulmasıyla,

- Elde edilen verilerin iyi bir şekilde saklanmasıyla,

- Çalışılan materyallerin ve araştırmacıların konumlarının tam olarak belirtilmesiyle,

- Çalışmanın tarafsız bir şekilde yapılmasıyla gerçekleştirilmiştir.

\section{BULGULAR}

Bir üniversitenin ilgili fakültesinde yer alan çocuk kütüphanesindeki 3-6 yaş grubu çocuklara yönelik hazırlanmış resimli öykü kitaplarındaki görsellerin ve metinlerin okuyuculara, olumlu/ olumsuz doğal çevre mesajı verme durumlarının incelenmesi amacıyla gerçekleştirilen bu nitel araştırmada aşağıdaki bulgular elde edilmiştir:

Resimli öykü kitaplarının doğrudan/dolaylı doğal çevre konusuna değinme ve canlı-doğal çevre etkileşimine yer verme durumlarına ilişkin bulgular Tablo 2'de verilmiştir.

Tablo 2

Resimli Öykü Kitaplarının Doğrudan/Dolaylı Doğal Çevre Konusuna Değinme ve Canlı-Doğal Çevre Etkileşimine Yer Verme Durumlarına Iliş̧kin Bulgular

\begin{tabular}{llrr}
\hline Değişkenler & Kategoriler & $\mathrm{f}$ & $\%$ \\
\hline Doğrudan/Dolaylı Doğal Çevre Konusuna & Doğrudan & 36 & 62,1 \\
Değinme Durumu & Dolaylı & 22 & 37,9 \\
\hline Canlı (İnsan/Hayvan/Bitki)-Doğal Çevre & İnsan - Doğal Çevre Etkileşimi & 39 & 67,2 \\
Etkileşimi & Hayvan - Doğal Çevre Etkileşimi & 17 & 29,3 \\
& Bitki - Doğal Çevre Etkileşimi & 2 & 3,5 \\
\hline Toplam & & 58 & 100,0 \\
\hline
\end{tabular}

Tablo 2 incelendiğinde, 58 kitabın \%62,1'inin $(n=36)$ doğal çevre konusuna doğrudan değindiği görülmektedir. Örneğin; K10'da doğal çevre mesajına değinmek amacıyla, çevre sorunu yaşayan bitkilerin, hayvanlardan yardım beklediğini gösterenmetinler ve görseller aşağıda verilmektedir.

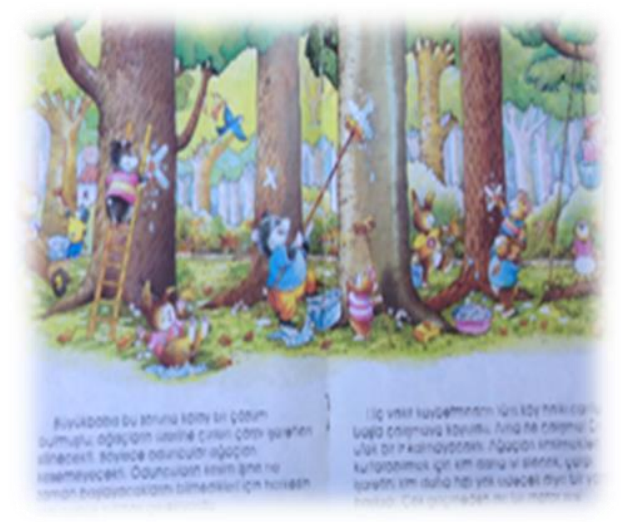

"Büyükbaba bu soruna kolay bir çözüm bulmuştu; ağaçların üzerine çizilen çarpı işaretleri silinecekti. Böylece oduncular ağaçları kesemeyecekti." "Eğer köyümüzün ağaçlarının kesilmesini istemiyorsak bu kararı verenlere yazmak, onlara ağaçların ne denli önemli olduğunu anlatmak gerekir.' dedi." 
58 kitabın \%37,9'unun ( $n=22)$ ise, doğal çevre konusuna dolaylı olarak değindiği görülmektedir. Örneğin; K3'te fiziksel özelliklerin insan ilişkilerini etkilememesi gerektiğini anlatmak amacıyla hazırlanan metinler ve görseller verilmektedir. Ancak kitapta,doğal çevre konusuna değinmeyi amaçlamadan, bitkilere zarar verme eylemi içeren metin ve görsel aşağıda yer almaktadır.

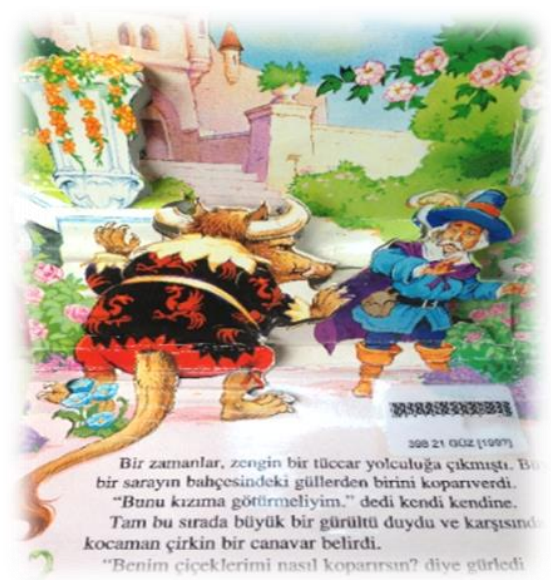

"Büyük bir sarayın bahçesindeki güllerden birini koparıverdi."

Kitapların \%67,2'sinde ( $n=39$ ) insan-doğal çevre etkileşimi bulunmaktadır. Örneğin; K56'da çocukların ağaçlarda eğlenceli vakit geçirdiklerini anlatan metinler ve görseller bulunmaktadır.

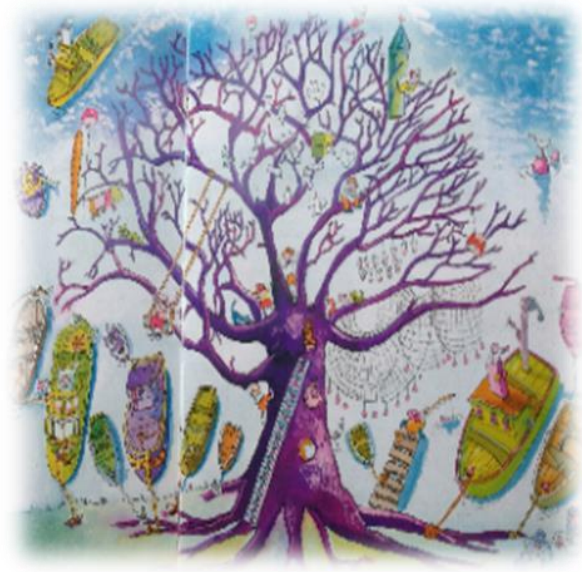

"Köyün çocukları, çınar ağacının üstünde gezinir, şarkı söyler, piknik yapar, dallarında kurdukları salıncaklarda sallanırlardı."

Kitapların \%29,3'ünde ( $n=17)$ hayvan-doğal çevre etkileşimi yer almaktadır. Örneğin; K27'de ayının çiçek fideleri alıp diğer hayvanlarla birlikte fideleri ormana dikmesini anlatan metinler ve görseller bulunmaktadır.

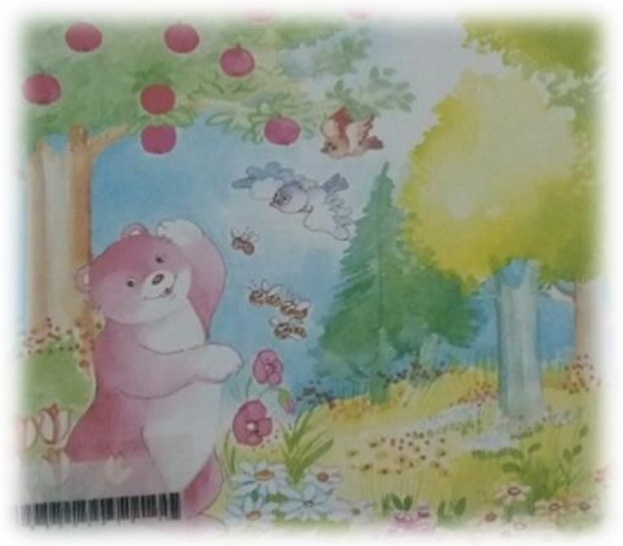

"Ayı hemen çiçek pazarına gitmiş, kazandığı tüm paralarla lale soğanları, çiçek tohumları, fideler almış. Ormana döndüğünde, diğer hayvanların da yardımıyla, fideleri ekmişler. Orman yeniden renklerine kavuşmuş. Çiçekler açmış. Ağaçlar meyve vermiş. Arılar bal yapmış. O güzel ve renkli ormanda, tüm hayvanlar, dostluk ve beraberlik içinde mutlu mutlu yaşamışlar." 
Kitapların \%3,5'inde ( $n=2$ ) bitki-doğal çevre etkileşimi görülmektedir. Örneğin; K15'de ağacın mutlulukla hayvanlara yaşam alanı sunmasını anlatan metinler ve görseller bulunmaktadır.

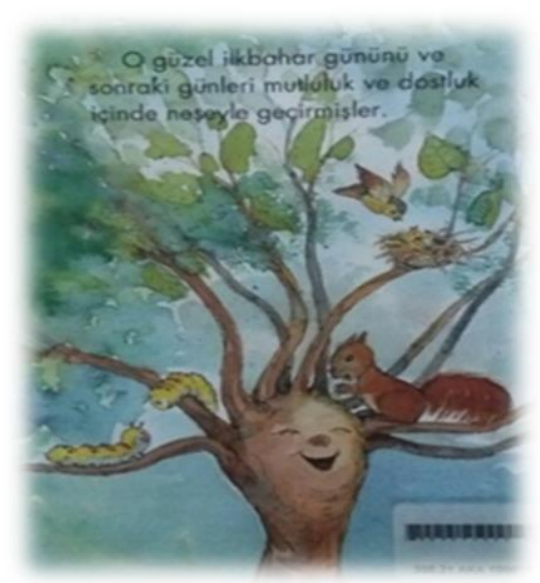

"Tomurcuklar hazırlamıs önce. Taze yapraklar büyütmüş. Sonra saçlarına bahar çiçekleri serpiştirmiş. Kendi farkında değilmiş ama gerçekten de dünyanın en güzel ağacı olmuş şimdi. Derken bir solucan başını çıkartmış topraktan. Sincap yavrusuyla çıkagelmiş. Kuşlar akın akın gelip ağacın saçlarına konmuşlar. Yumurtadan çıkan tırtıllar yapraklarına yerleşmişler. O güzel ilkbahar gününü ve sonraki günleri mutluluk ve dostluk içinde neşeyle geçirmişler."

Resimli öykü kitaplarında, canlıların doğal çevre ile olan etkileşiminin, okuyucuya olumlu/olumsuzdoğal çevre mesajları verme durumu söz konusudur. Bu nedenle,resimli öykü kitaplarında yer alan canlı-doğal çevre etkileşimleri incelendikten sonra, bu etkileşim yoluyla verilen olumlu/olumsuzdoğal çevre mesajları incelenmiş ve temalandırılmıştır. Resimli öykü kitaplarında verilen olumlu/olumsuz doğal çevre mesajlarının temalarına ilişkin bulgular Tablo 3'de verilmiştir.

Tablo 3

Olumlu/Olumsuz Doğal Çevre Mesajları İ̧̧eren Resimli Öykü Kitaplarında Verilen Mesajların Temalarına ilişsin Bulgular

\begin{tabular}{llrr}
\hline Doğal Çevre Mesajının & \multicolumn{1}{c}{ Tema } & \multicolumn{2}{c}{$\%$} \\
Olumlu/Olumsuz Olma Durumu & Bitkiler & 25 & 43,1 \\
& Hayvanlar & 11 & 19,0 \\
Olumlu & Birden Fazla Doğa Unsuru & 5 & 8,6 \\
& Toprak & 3 & 5,2 \\
& Su & 3 & 5,2 \\
& Hava & 1 & 1,7 \\
\hline Toplam & & 48 & 82,8 \\
\hline \multirow{3}{*}{ Olumsuz } & Bitkiler & 6 & 10,3 \\
& Hayvanlar & 3 & 5,2 \\
\hline Toplam & Su & 1 & 1,7 \\
\hline Genel toplam & & 10 & 17,2 \\
\hline
\end{tabular}

Tablo 3 incelendiğinde, değerlendirmeye alınan toplam 58 resimli öykü kitabının \%82,7'sinde $(n=48)$ olumlu doğal çevre mesajı olduğu görülmektedir. Kitapların \%43,1'i $(n=25)$ "Bitkiler" temasında olumlu doğal çevre mesajı içermektedir. Örneğin; K33'de ağaç dikmenin gerekliliğini anlatan metinler ve görseller bulunmaktadır. Kitapların \%19'u $(n=11)$ "Hayvanlar" temasında olumlu doğal çevre mesajı içermektedir. Örneğin; K40' da yaralı bir hayvana yardım etmenin önemini anlatan metinler ve görseller bulunmaktadır. Kitapların \%8,6'sında $(n=5)$ "Birden Fazla Doğa Unsuru" temasında olumlu doğal çevre mesajları bulunmaktadır. Örneğin; K19'da ağaç ve toprağı bilinçli kullanmanın yararlarını anlatan metinler ve görseller bulunmaktadır. Kitapların \%5,2'si $(n=3)$ "Toprak" temasında olumlu doğal çevre mesajı içermektedir. Örneğin; K25'de zararlı atıkların toprağa karışmaması gerektiğini anlatan metinler ve görseller bulunmaktadır. Kitapların \%5,2'i $(n=3)$ "Su" temasında olumlu doğal çevre mesajı içermektedir. Örneğin; K47'de kirli suların göllere, denizlere karışmadan önce arıtılması gerekliliğini anlatan metinler ve görseller bulunmaktadır. Kitapların $\% 1,7$ 'sinde $(n=1)$ ise "Hava" temasında olumlu doğal çevre mesajı yer almaktadır. Örneğin; K49'da 
kirletilen havanın temizlenmesi için harekete geçmenin gerekliliğini anlatan metinler ve görseller bulunmaktadır.

Tablo 3 incelendiğinde, toplam 58 resimli öykü kitabının \%17,2'sinde $(n=10)$ ise olumsuz doğal çevre mesajı olduğu belirlenmiştir. Kitapların \%10,3'ü $(n=6)$ "Bitkiler" temasında olumsuz doğal çevre mesajı içermektedir. Örneğin; K2'de yeşil bir ağacı balta ile kesmeyi anlatan metinler ve görseller bulunmaktadır. Kitapların \%5,2'si $(n=3)$ "Hayvanlar" temasında olumsuz doğal çevre mesajı içermektedir. Örneğin; K46'da bazı durumlarda hayvanlara acı çektirmenin doğal karşılanabileceğini anlatan metinler ve görseller bulunmaktadır. Kitapların \%1,7'si ise $(n=1)$ "Su" temasında olumsuz doğal çevre mesajı içermektedir. Örneğin; K58'de suların kirletilmesine tepki vermeyerek yaşam alanlarının terk edilmesini anlatan metinler ve görseller bulunmaktadır.

Resimli öykü kitaplarında yer alan temalar ve verilen olumlu/olumsuz doğal çevre mesajlarını içeren bulgular Tablo 4'te verilmiştir:

Tablo 4

Resimli Öykü Kitaplarında Yer Alan Temalara Yönelik Olarak Verilen Olumlu / Olumsuz Doğal Çevre Mesajı Ile Ilgili Bulgular

\begin{tabular}{|c|c|c|c|c|}
\hline $\begin{array}{l}\text { Doğal Çevre } \\
\text { Mesajı }\end{array}$ & Tema & Verilen Mesaj & $f$ & $\%$ \\
\hline \multirow{23}{*}{ Olumlu } & \multirow{3}{*}{$\begin{array}{l}\text { Birden Fazla } \\
\text { Doğa } \\
\text { Unsuru }\end{array}$} & "Doğa Unsurlarını Korumalıyız." & 2 & 3,4 \\
\hline & & “Doğa Unsurlarını Korumak İçin Önlem Almalıyız." & 2 & 3,4 \\
\hline & & “Doğa Unsurlarının Öneminin Farkına Varmalıyız." & 1 & 1,7 \\
\hline & \multirow{9}{*}{ Bitkiler } & "Bitkilere Verilen Zararları Telafi Etmeliyiz." & 5 & 8,6 \\
\hline & & "Bitkilere Verilen Zararları Telafi Etmeye Çalışmalıyız." & 3 & 5,2 \\
\hline & & "Bitkilere Zarar Verme Endişesi Duymalıyız." & 3 & 5,2 \\
\hline & & $\begin{array}{l}\text { "Bitkilere Verilen Zararları Telafi Etmek İçin Diğerlerini } \\
\text { Bilinçlendirmeliyiz." }\end{array}$ & 3 & 5,2 \\
\hline & & "Bitkilerin Zarar Görmelerini Engellemeliyiz." & 3 & 5,2 \\
\hline & & "Bitkilerin Canlı Varlıklar Olduklarının Farkına Varmalıyız." & 3 & 5,2 \\
\hline & & "Bitkilere Zarar Vermekten Kaçınmalıyız." & 2 & 3,4 \\
\hline & & "Bitkilerin Zarar Görmelerine Karşı Duyarlılık Göstermeliyiz." & 2 & 3,4 \\
\hline & & $\begin{array}{l}\text { "Bitkilerin Zarar Görmelerinin Olumsuz Sonuçlarının Farkına } \\
\text { Varmalıyız." }\end{array}$ & 1 & 1,7 \\
\hline & \multirow{5}{*}{ Hayvanlar } & "Hayvanların Yaşam Alanlarının Farkına Varmalıyız." & 4 & 6,9 \\
\hline & & "Hayvanlara Yardım Etmeliyiz." & 3 & 5,2 \\
\hline & & "Hayvanların Canlı Varlıklar Olduklarının Farkına Varmalıyız." & 2 & 3,4 \\
\hline & & "Hayvanların Yaşam Alanlarına Müdahale Etmemeliyiz." & 1 & 1,7 \\
\hline & & "Hayvanlara Verilen Zararları Telafi Etmeye Çalışmalıyız." & 1 & 1,7 \\
\hline & \multirow[t]{2}{*}{ Toprak } & "Toprağa Verilen Zararları Telafi Etmeliyiz." & 2 & 3,4 \\
\hline & & "Toprağa Verilen Zararları Engellemeliyiz." & 1 & 1,7 \\
\hline & \multirow{3}{*}{$\mathrm{Su}$} & "Suya Verilen Zararların Farkına Varmalıyız." & 1 & 1,7 \\
\hline & & "Suya Verilen Zararları Telafi Etmeliyiz." & 1 & 1,7 \\
\hline & & $\begin{array}{l}\text { "Suya Verilen Zararları Telafi Etmek İçin Diğerlerini } \\
\text { Bilinçlendirmeliyiz." }\end{array}$ & 1 & 1,7 \\
\hline & Hava & $\begin{array}{l}\text { "Havaya Verilen Zararları Telafi Etmek İçin Diğerlerini } \\
\text { Bilinçlendirmeliyiz." }\end{array}$ & 1 & 1,7 \\
\hline Toplam & & & 48 & 82,8 \\
\hline \multirow{3}{*}{ Olumsuz } & Bitki & "Bitkilere İstediğimizde Zarar Verebiliriz." & 6 & 10,3 \\
\hline & Hayvan & "Hayvanlara İstediğimizde Zarar Verebiliriz." & 3 & 5,2 \\
\hline & Su & "Suya Verilen Zararlara Tepkisiz Kalabiliriz." & 1 & 1,7 \\
\hline Toplam & & & 10 & 17,2 \\
\hline Genel Toplam & & & 58 & 100 \\
\hline
\end{tabular}


Burcu ÇABUK - Tuğba BAŞ - Nergiz TEKE

\section{a. Olumlu Doğal Çevre Mesajları}

Tablo 4. Incelendiğinde, 58 kitabın $\% 82,8^{\prime}$ inde $(n=48)$ olumlu doğal çevre mesajı verildiği görülmektedir. Bu mesajlara ilişkin bulgular aşağıda detaylı olarak verilmiştir:

Tablo 4'te "Birden Fazla Doğa Unsuru" temasıyla ilgili olarak 3 olumlu doğal çevre mesajının işlendiği görülmektedir.

Kitapların \%3,4'ünde (n=2) (K19 ve K39) "Doğa Unsurlarını Korumalıyız." mesajının olduğu belirlenmiştir. Bu mesajla ilgili K39'daki örnek metin ve görsel aşağıda yer almaktadır:

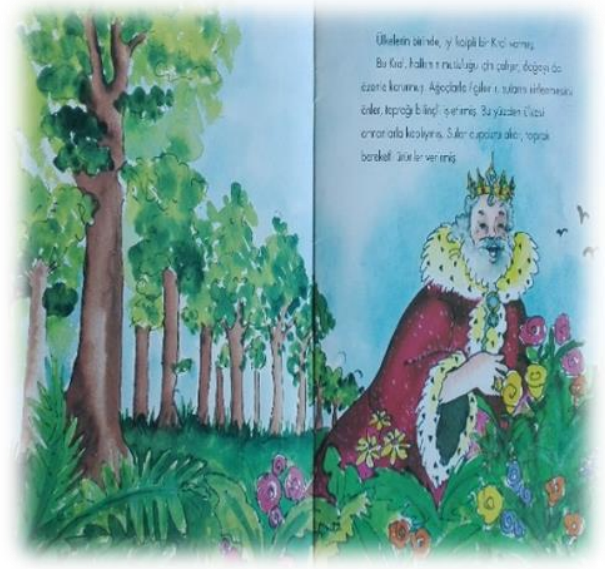

"Bu kral halkının mutluluğu için çalışır, doğayı özenle korurmuş. Ağaçlarla ilgilenir, suların kirlenmesini önler, toprağı bilinçli işletirmiş. Bu yüzden ülkesi ormanlarla kaplıymış. Sular dupduru akar, toprak bereketli ürünler verirmiş."

Örnekte yer alan metin ve görsel aracılığıyla verilen bu mesaj, okuyucuda "Insanları mutlu etmek için doğa ve özelde ağaçlar korunarak suların kirlenmesi engellenirse, su temiz kalır. Toprak bilinçli işlenirse, bol miktarda ürün elde edilir. Doğayı korumak, tüm canlıların yararınadır." algısını oluşturabilir.

Kitapların \%3,4'ünde ( $n=2$ ) (K7 ve K22) "Doğa Unsurlarını Korumak İçin Önlem Almalıyız." mesajının olduğu belirlenmiştir. Bu mesajla ilgili K22'deki örnek metin ve görsel aşağıda yer almaktadır:

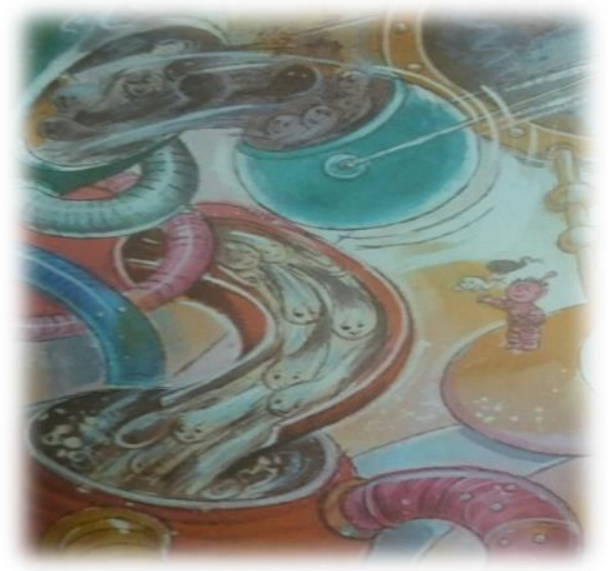

"Uzaylı çocuk açıklamış, 'Bu makineler bütün pislikleri temizler. Biz fabrikayı kurmadan önce, ilk iş olarak bu temizleme makinelerini yaparız. Yoksa ülkemiz kirlenir, bütün güzellikler renklerini, canlılığını kaybeder, insanlarımız gülmeyi unutur."'

Örnekte yer alan metin ve görsel aracılığıyla verilen bu mesaj, okuyucuda "Çevreyi korumak için çabalamak gerekir. Gereken önlemler alınmazsa, sonuçları canlılar için zararlıdır." algısını oluşturabilir.

Kitapların \%1,7'sinde ( $\mathrm{n}=1$ ) "Doğa Unsurlarının Öneminin Farkına Varmalıyız." mesajının olduğu belirlenmiştir. Bu mesajla ilgili K54'deki örnek metin ve görsel aşağıda yer almaktadır: 


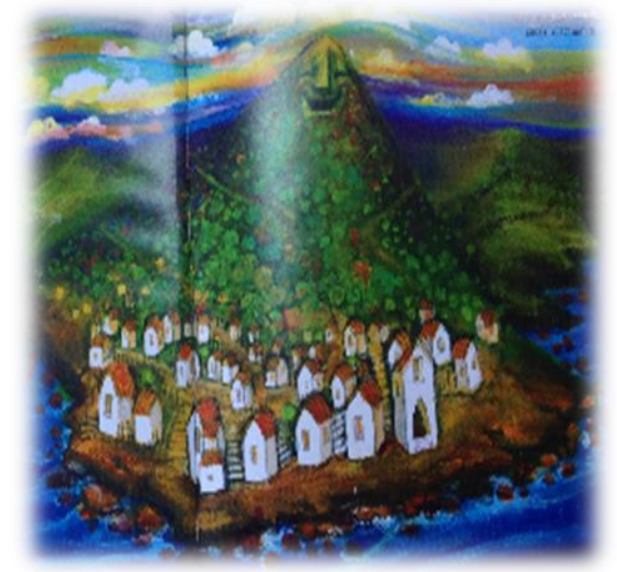

"Onlar için dağ, bolluk, bereket, ... Dağ köy için ekmekti, suydu, yoldu."

Örnekte yer alan metin ve görsel aracılı̆̆ıyla verilen bu mesaj, okuyucuda "Dağ özelinde doğa, yaşam için önemlidir. Canlıların varlıklarını sürdürebilmeleri için doğanın değerini bilmeleri gerekmektedir." algısını oluşturabilir.

Tablo 4'te "Bitkiler" teması ile ilgili olarak 9 olumlu doğal çevre mesajının işlendiği görülmektedir.

Kitapların \%8,6'sında ( $n=5)(K 20, K 23, K 27, K 34$ ve K56) "Bitkilere Verilen Zararları Telafi Etmeliyiz." mesajının olduğu görülmektedir. Bu mesajla ilgili K27'deki örnek metin ve görsel aşağıda yer almaktadır:

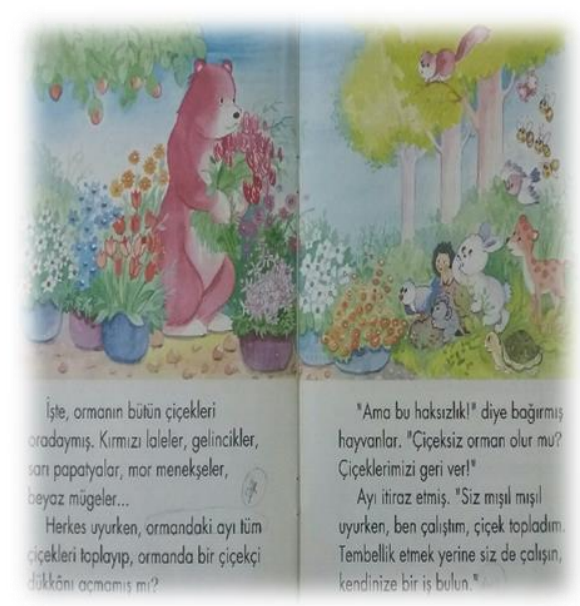

"Ayı hemen çiçek pazarına gitmiş, kazandığı tüm paralarla lale soğanları, çiçek tohumları, fideler almış. Ormana döndüğünde, diğer hayvanların da yardımıyla, fideleri ekmişler. Orman yeniden renklerine kavuşmuş. Çiçekler açmış. Ağaçlar meyve vermiş. Arılar bal yapmış. O güzel ve renkli ormanda, tüm hayvanlar, dostluk ve beraberlik içinde mutlu mutlu yaşamışlar."

Örnekte yer alan metin ve görsel aracilığıyla verilen bu mesaj, okuyucuda "Orman tahrip olduğunda tohumlar ekilip fideler dikilerek ormanın tekrar canlandırıması desteklenmelidir. Orman canlanınca, içinde yaşayan canlı varlıklarla birlikte yaşam döngüsü de devam eder." algısını oluşturabilir.

Kitapların \%5,2'sinde ( $\mathrm{n}=3$ ) (K4, K44 ve K50) “Bitkilere Verilen Zararları Telafi Etmeye Çalışmalıyız." mesajının olduğu belirlenmiştir. Bu mesajla ilgili $\mathrm{K} 50$ 'deki örnek metin ve görsel aşağıdaki gibi yer almaktadır:

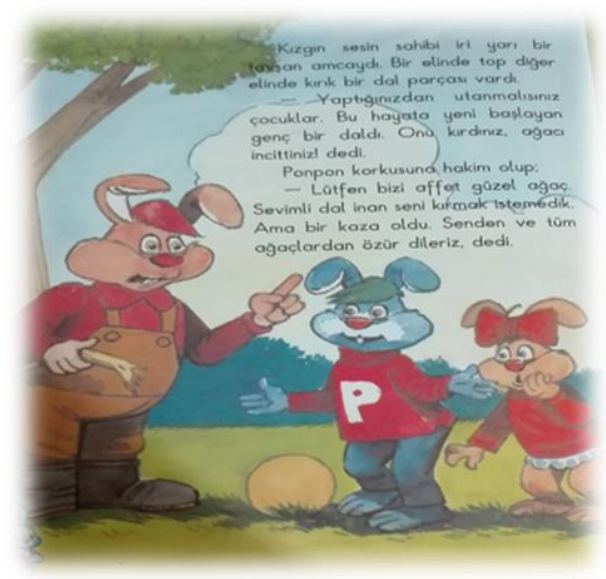

"Lütfen bizi affet güzel ağaç. Sevimli dal inan seni kırmak istemedik. Ama bir kaza oldu. Senden ve tüm ağaçlardan özür dileriz." 
Örnekte yer alan metin ve görsel aracılığıyla verilen bu mesaj, okuyucuda "Ağaçların da canlı olduğunu unutmamalı ve yanlışıkla da olsa ağaçlara zarar verildiğinde, pişmanlık duyulmalıdır." algısını oluşturabilir.

Kitapların \%5,2'sinde ( $n=3$ ) (K31, K41 ve K51) "Bitkilere Zarar Verme Endişesi Duymalıyız." mesajının olduğu belirlenmiştir. Bu mesajla ilgili K31'deki örnek metin ve görsel aşağıda yer almaktadır:

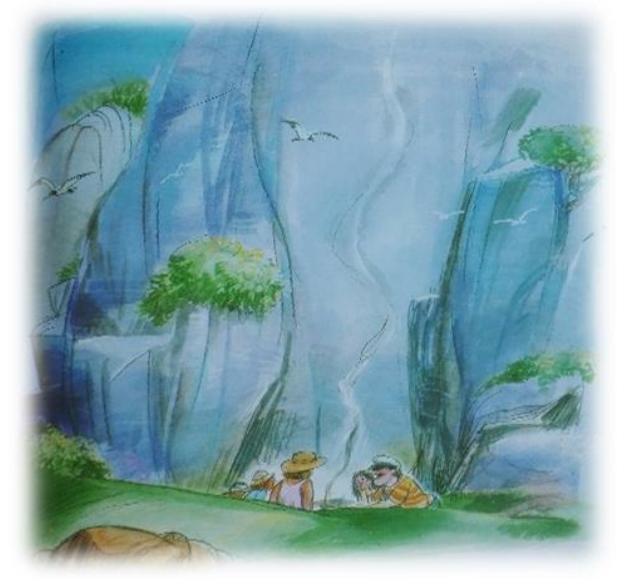

"Kumsalın arkası hemen ormandı. Oralarda ateş yakmak tehlikeliydi. Küçük bir kıvılcım ormanı tutuşturabilirdi."

Örnekte yer alan metin ve görsel aracılığıyla verilen bu mesaj, okuyucuda "Ormanda söndürülmeden bırakılan ateş tehlikelidir çünkü büyüyerek tüm ormanın yanması gibi büyük zararlara yol açacağı düşünülmelidir." algısını oluşturabilir.

Kitapların \%5,2'sinde ( $\mathrm{n}=3)$ (K26, K33 ve K48) "Bitkilere Verilen Zararları Telafi Etmek İçin Diğerlerini Bilinçlendirmeliyiz." mesajının olduğu belirlenmiştir. Bu mesajla ilgili K48'deki örnek metin ve görsel aşağıdaki gibi yer almaktadır:

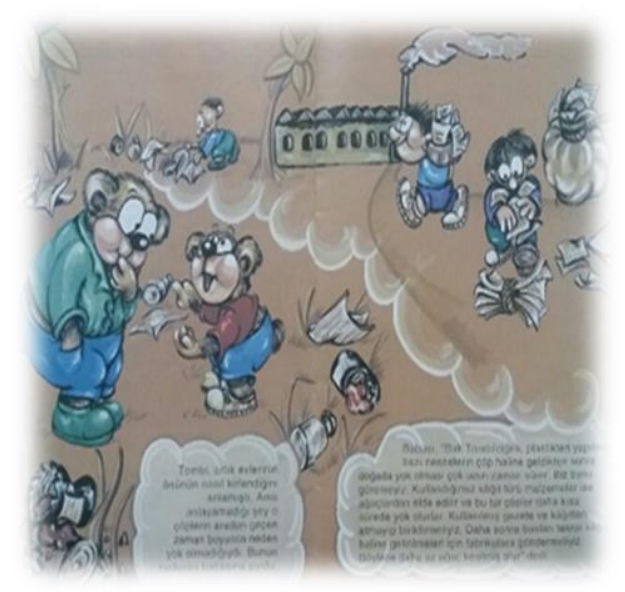

"Babası, 'Bak Tombi'ciğim, plastikten yapılmış bazı nesnelerin çöp haline geldikten sonra doğada yok olması çok uzun zaman sürer. Biz bunu göremeyiz. Kullandığımız kağıt türü malzemeler ise ağaçlardan elde edilir ve bu tür çöpler daha kısa sürede yok olurlar. Kullanılmış gazete ve kağıtları atmayıp biriktirmeliyiz. Daha sonra bunları tekrar kağıt haline getirilmeleri için fabrikalara göndermeliyiz. Böylece daha az ağaç kesilmiş olur' dedi."

Örnekte yer alan metin ve görsel aracılığıyla verilen bu mesaj, okuyucuda "Kağıt, plastik, cam gibi doğada uzun sürede çözünemeyen materyallerin, doğaya atılmayıp yeniden kullanılarak geridönüşümlerinin sağlanması konusunda diğerlerini uyarmalıyız." algısını oluşturabilir.

Kitapların \%5,2'sinde (n=3) (K5, K10 ve K12) "Bitkilerin Zarar Görmelerini Engellemeliyiz." mesajının olduğu belirlenmiştir. Bu mesajla ilgili $\mathrm{K}^{\prime}$ 'deki örnek metin ve görsel aşağıdaki gibi yer almaktadır: 


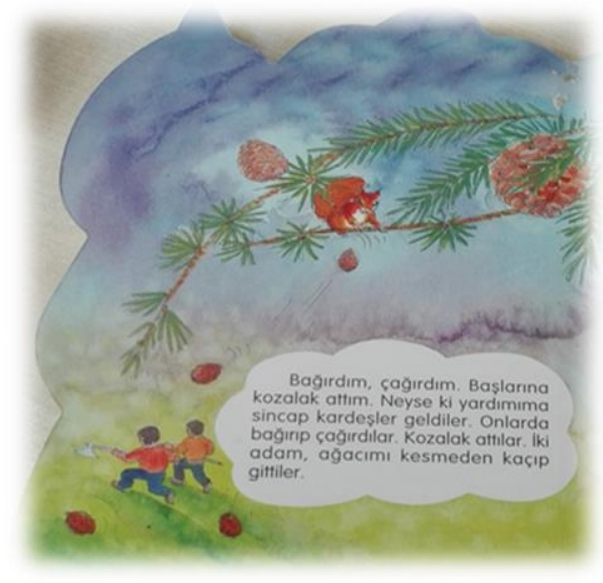

"Bağırdım çağırdım. Başlarına kozalak attım. Neyse ki yardımıma sincap kardeşler geldiler. Onlarda bağırıp çağırdılar. Kozalak attılar. Iki adam, ağacımı kesmeden kaçıp gittiler."

Örnekte yer alan metin ve görsel aracılığıyla verilen bu mesaj, okuyucuda "Ağaçlara ve genel olarak doğaya zarar verebilecek tehditlere karşı önlem alınmalı ve doğaya sahip çıkılmalıdır." algısını oluşturabilir.

Kitapların \%5,2'sinde (n=3) (K14, K30 ve K42) “Bitkilerin Canlı Varlıklar Olduklarının Farkına Varmalıyız." mesajının olduğu belirlenmiş̧ir. Bu mesajla ilgili K14'deki örnek metin ve görsel aşağıdaki gibi yer almaktadır:

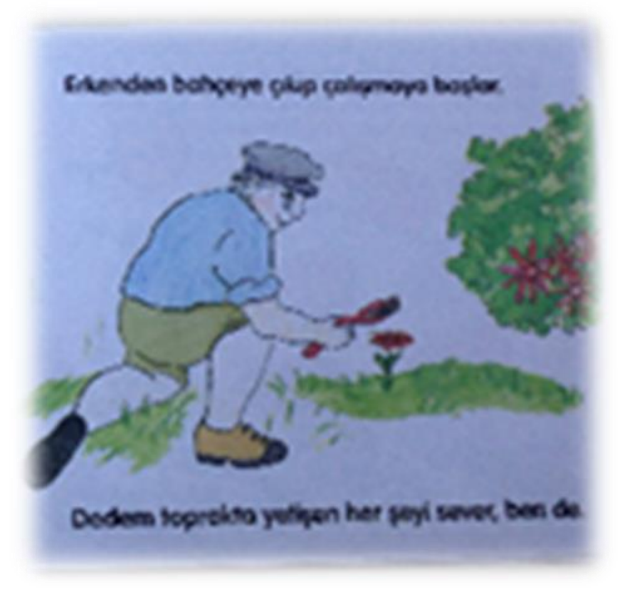

"Dedem toprakta yetişen her şeyi sever, ben de... Bahçeyi sularken dedem gülleriyle konuşur. (Biliyorsunuz, değil mi, çiçeklerin güzel büyümeleri için onlarla konuşmak gerekirmiş.)"

Örnekte yer alan metin ve görsel aracılığıyla verilen bu mesaj, okuyucuda "Bitkilerin de canlı varlıklar olduğu bilinciyle davranışlara dikkat edilmelidir." algısını oluşturabilir.

Kitapların \%3,4'ünde (n=2) (K32 ve K35) "Bitkilere Zarar Vermekten Kaçınmalıyız." mesajının olduğu belirlenmiştir. Bu mesajla ilgili K32'deki örnek metin aşağıdaki gibi yer almaktadır:

"Parktaki çiçekler, orayı güzelleştirmek için dikiliyor. Parka gidenler, onlara bakarak, sevinip neşeleniyor. Oradaki çiçekler, hepimizin. Bu yüzden onları koparmak doğru olmaz.

Örnekte yer alan metin aracılığıyla verilen bu mesaj, okuyucuda "Doğayı güzelleştiren ve insanlara mutluluk veren bitkilere zarar verilmemelidir." algısını oluşturabilir.

Kitapların \%3,4'ünde ( $\mathrm{n}=2$ ) (K9 ve K11) "Bitkilerin Zarar Görmelerine Karşı Duyarlılık Göstermeliyiz." mesajının olduğu belirlenmiştir. Bu mesajla ilgili $\mathrm{K9}$ 'daki örnek metin ve görsel aşağıdaki gibi yer almaktadır: 


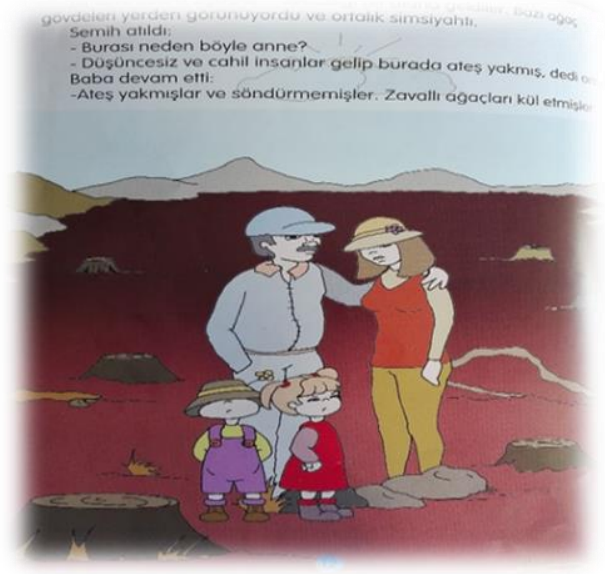

"Düşüncesiz ve cahil insanlar gelip burada ateş yakmış dedi anne. Baba devam etti: Ateş yakmışlar ve söndürmemişler. Zavallı ağaçları kül etmişler."

Örnekte yer alan metin ve görsel aracılığıyla verilen bu mesaj, okuyucuda "Ormanda ateş yakmak yanlış yapılan bir davranıştır ve ormanda yaşayan canlılara zarar verir. Bu konuda dikkatli ve özenli olunmalıdır." algısını oluşturabilir.

Kitapların \%1,7'sinde ( $\mathrm{n}=1$ ) (K28) “Bitkilerin Zarar Görmelerinin Olumsuz Sonuçlarının Farkına Varmalıyız." mesajının olduğu belirlenmiştir. Bu mesajla ilgili K28'deki örnek metin ve görsel aşağıdaki gibi yer almaktadır:

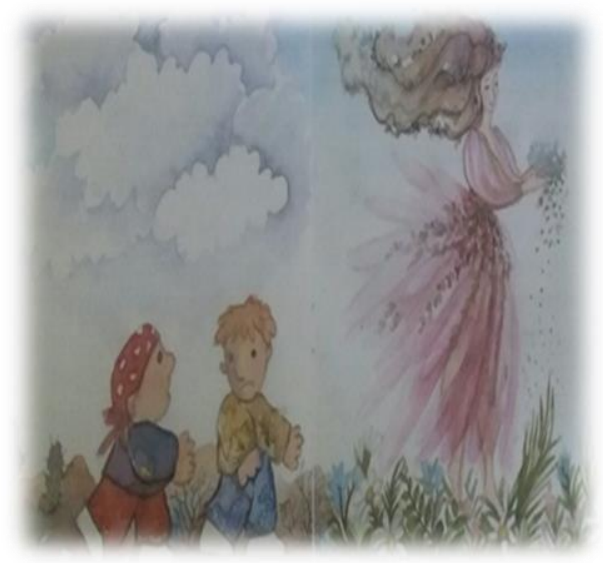

"Orman cüceleri, 'Galiba doğa bize kızgın,' demişler. 'Öyle olmalı' demiş orman perisi. 'Siz doğaya zarar veriyordunuz. Şimdi de doğa sizden kaçıp gizleniyor işte!' Ormanın yeni komşuları o günden sonra doğayı sevmenin, onu korumak olduğunu anlamışlar."

Örnekte yer alan metin ve görsel aracılığıyla verilen bu mesaj, okuyucuda "Doğaya zarar verildiğinde, zarar veren de dâhil, tüm canlıların olumsuz etkileneceği bilinmelidir ve dikkatli olunmalıdır." algısını oluşturabilir.

Tablo 4'te "Hayvanlar" temasıyla ilgili olarak 5 olumlu doğal çevre mesajının işlendiği görülmektedir.

Kitapların \%6,9'unda (n=4) (K1, K15, K16 ve K29) "Hayvanların Yaşam Alanlarının Farkına Varmalıyız." mesajının olduğu belirlenmiştir. Bu mesajla ilgili K29'daki örnek metin ve görsel aşağıdaki gibi yer almaktadır:

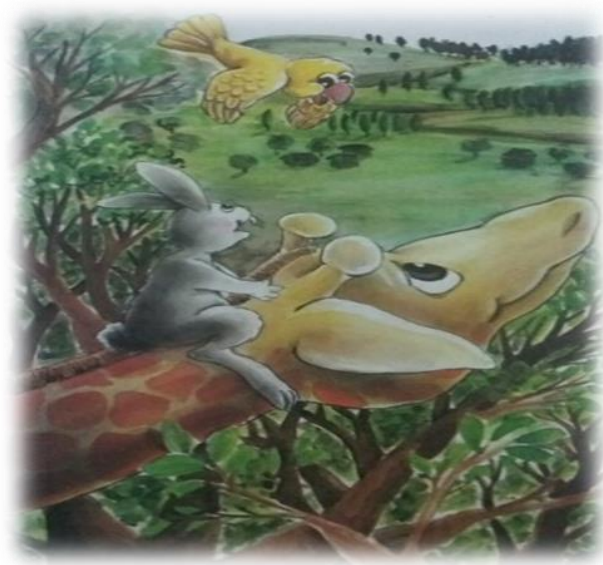

"Ama yediğin bütün yapraklar benim evimin bahçesi... Neredeyse yuvamı da kocaman ağzına alıp yutacaktın." demiş kuş. Zürafa çok üzülmüş. 'Burada yuvan olduğunu bilmiyordum. Öyleyse ben de başka bir ağacın yapraklarını yerim.'

Ama ya başka ağaçta da, başka bir kuşun yuvası varsa? Kuş ona yardım etmeyi önermiş.' istersen benönden uçup bakayım. Eğer yaprakların arasında gizlenmiş bir yuva varsa sana haber veririm. 
Örnekte yer alan metin ve görsel aracılığıyla verilen bu mesaj, okuyucuda "Başka canlıların yaşam alanlarına saygılı olunmalıdır. Bu alanlara zarar verildiğinde, canlıların hayatlarının tehlikeye girebileceği düşünülmelidir." algısını oluşturabilir.

Kitapların \%5,2'sinde ( $\mathrm{n}=3$ ) (K37, K38 ve K53) "Hayvanlara Yardım Etmeliyiz." mesajının olduğu belirlenmiştir. Bu mesajla ilgili K38'deki örnek metin ve görsel aşağıdaki gibi yer almaktadır:

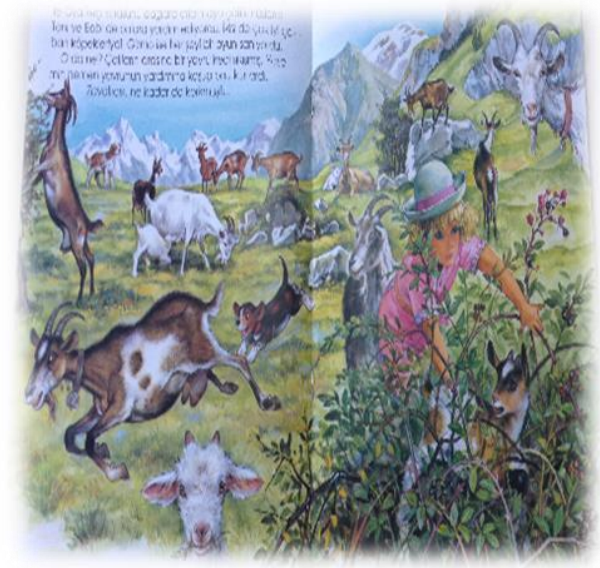

"Çalıların arasına bir yavru keçi sıkışmış. Yasemin hemen yavrunun yardımına koşup onu kurtardı."

Örnekte yer alan metin ve görsel aracılığıyla verilen bu mesaj, okuyucuda "Duyarlı davranılarak, ihtiyaç duyduklarında, diğer canlılara destek olunmalıdır." algısını oluşturabilir.

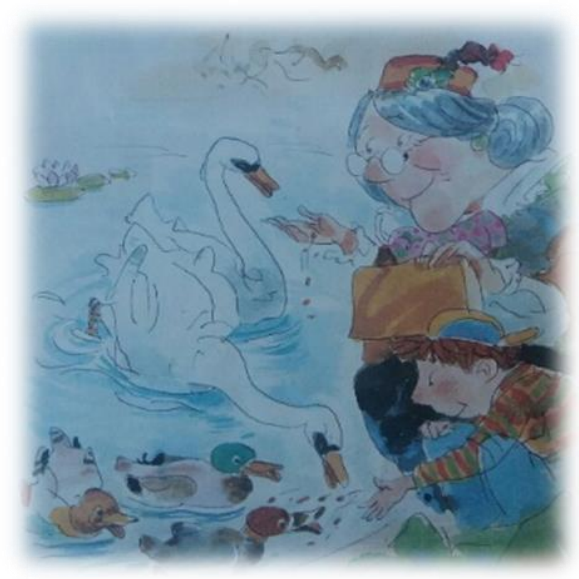

Kitapların \%3,4'ünde ( $\mathrm{n}=2) \quad(K 8$ ve K21) "Hayvanların Canlı Varlıklar Olduklarının Farkına Varmalıyız." mesajının olduğu belirlenmiştir. Bu mesajla ilgili K21'deki örnek metin ve görsel aşağıdaki gibi yer

Örnekte yer alan metin ve görsel aracılığıyla verilen bu mesaj, okuyucuda "Hayvanların canlı olmaları nedeniyle beslenme gibi ihtiyaçları olduğunun bilincine varılmalıdır." algısını oluşturabilir.

Kitapların \%1,7'sinde (n=1) (K13) "Hayvanların Yaşam Alanlarına Müdahale Etmemeliyiz." mesajının olduğu belirlenmiştir. Bu mesajla ilgili K13'dekiörnek metin ve görsel aşağıdaki gibi yer almaktadır:

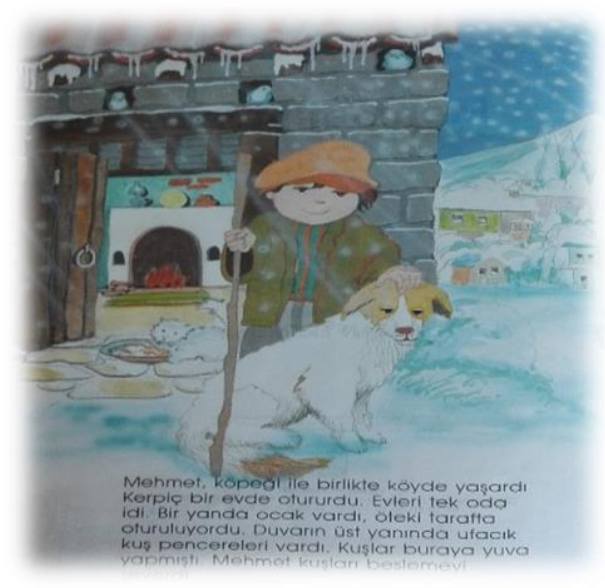

"Mehmet, köpeği ile köyde yaşardı. Kerpiç bir evde otururdu. Evleri tek oda idi. Bir yanda ocak vardı öteki tarafta oturuluyordu. "Duvarın üst yanında ufacık kuş pencereleri vardı. Kuşlar buraya yuva yapmıştı. Mehmet kuşları beslemeyi severdi." 
Örnekte yer alan metin ve görsel aracılığıyla verilen bu mesaj, okuyucuda "Canlı varlıklar olan hayvanların bir ihtiyacı da barınmadır ve canlıların yaşam alanlarına dokunulmamalıdır." algısını oluşturabilir.

Kitapların \%1,7'sinde ( $\mathrm{n}=1$ ) (K40) "Hayvanlara Verilen Zararları Telafi Etmeye Çalışmalıyız." mesajının olduğu belirlenmiştir. Bu mesajla ilgili K40'dakiörnek metin ve görsel aşağıdaki gibi yer almaktadır:

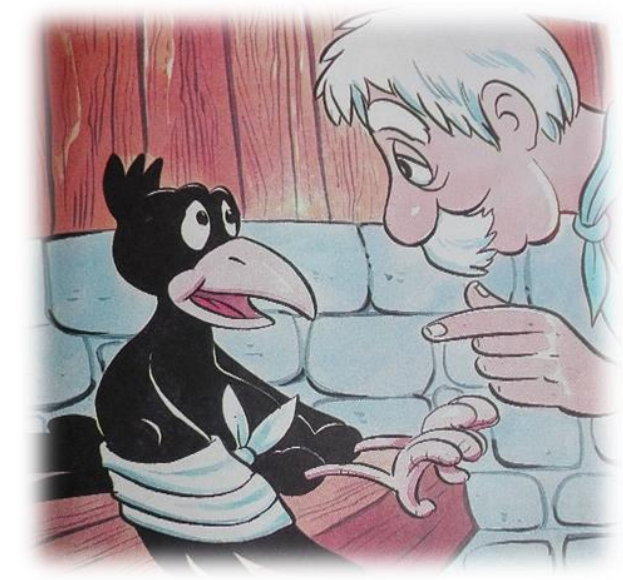

"Karga acıyla yerde çırpınırken zavalı çiftçi onu almış ve evine götürmüş. Karga korkudan çırpınıp duruyormuş. Korkma demiş kargaya. Sana yardım edeceğim."

Örnekte yer alan metin ve görsel aracılığıyla verilen bu mesaj, okuyucuda "Canlılara yardım etmeliyiz. Yaralanma gibi durumlarda tedavi olmalarını sağlamalıyız." algısını oluşturabilir.

Tablo 4'te "Toprak" temasıyla ilgili olarak 2 olumlu doğal çevre mesajının işlendiği görülmektedir.

Kitapların \%3,4'ünde (n=2) (K24 ve K52) "Toprağa Verilen Zararları Telafi Etmeliyiz." mesajının olduğu belirlenmiştir. Bu mesajla ilgili K52'dekiörnek metin ve görsel aşağıdaki gibi yer almaktadır:

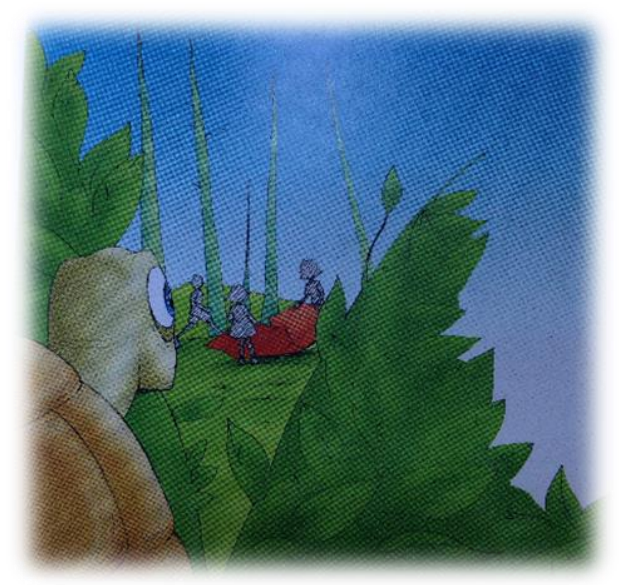

"-Hiçbir şey yok. Bir meyve kabuğu, küçücük bir kağıt parçası bile yok ortada.

-Her şeyi toplayıp götürdüler.

- Kim götürdü?

- Kim olacak, insanlar. Yani çocuklar. Bütün çöplerini topladılar güzelce ve götürdüler."

Örnekte yer alan metin ve görsel aracılı̆̆ıyla verilen bu mesaj, okuyucuda "Toprağın değerli olduğunu bilerek, üzerinde zaman geçirdikten sonra, atık gibi toprağa zararlı maddeleri ortadan kaldırmalıyız." algııını oluşturabilir.

Kitapların \%1,7'sinde ( $\mathrm{n}=1$ ) (K25) "Toprağa Verilen Zararları Engellemeliyiz." mesajının olduğu belirlenmiştir. Bu mesajla ilgili K25'deki örnek metin ve görsel aşağıdaki gibi yer almaktadır: 


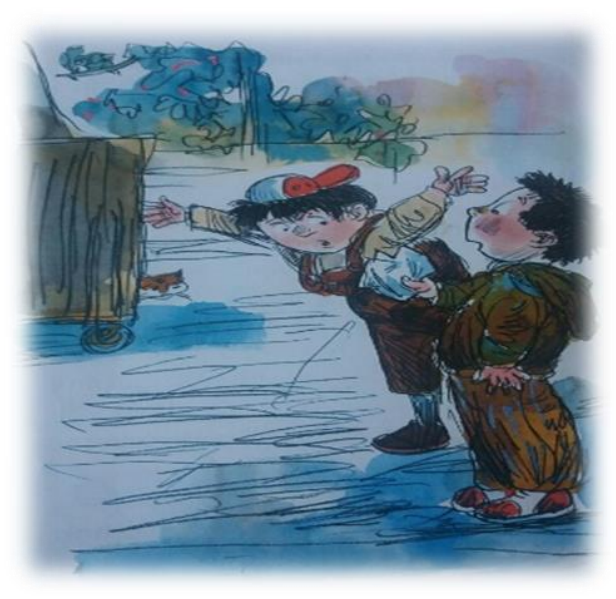

"'Aaaa, şuraya bak! Yere bir kâğıt parçası düşmüşs,' demiş çocuklardan biri. 'Haydi, kaldırıp çöpe atalım.' Uzanıp kâğıdı yerden almış. Kâğıdı çöpe atmışlar. Buruşuk kâğıt parçası çok mutlu olmuş."

Örnekte yer alan metin ve görsel aracılığıyla verilen bu mesaj, okuyucuda "Toprağa zarar verici davranışı kendimiz yapmasak bile, doğaya duyarlılık gösterip, potansiyel tehlikeleri önlemek için çaba göstermeliyiz." algısını oluşturabilir.

Tablo 4'te "Su" temasıyla ilgili olarak 3 olumlu doğal çevre mesajının işlendiği görülmektedir.

Kitapların \%1,7'sinde ( $\mathrm{n}=1$ ) (K47) "Suya Verilen Zararların Farkına Varmalıyız." mesajının olduğu belirlenmiştir. Bu mesajla ilgili K47'dekiörnek metin ve görsel aşağıdaki gibi yer almaktadır:

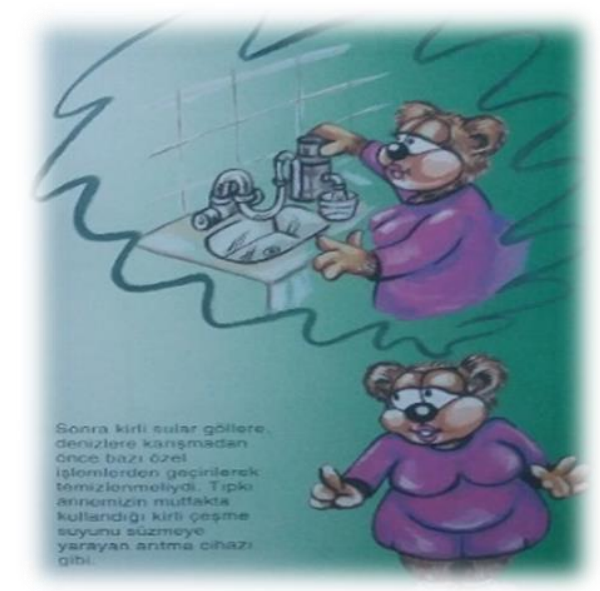

"Sonra kirli sular göllere, denizlere karışmadan önce bazı özel işlemlerden geçirilerek temizlenmeliydi. Tıpkı annemizin mutfakta kullandığı kirli çeşme suyunu süzmeye yarayan arıtma cihazı gibi."

Örnekte yer alan metin ve görsel aracılığıyla verilen bu mesaj, okuyucuda "Kirli suların; temiz suları ve diğer doğa unsurlarını kirletebileceği bilinmelidir." algısını oluşturabilir.

Kitapların \%1,7'sinde ( $\mathrm{n}=1$ ) (K55) "Suya Verilen Zararları Telafi Etmeliyiz." mesajının olduğu belirlenmiştir. Bu mesajla ilgili K55'deki örnek metin aşağıdaki gibi yer almaktadır:

"Hemen bir toplantı yapıp, çöpleri toplamaya karar verdiler. Çöpler toplanınca kumlar yeniden çıktı ortaya. Güneş, kumların üstündeki pislikleri kurutup pırıl pırıl yaptı." (Örnekte bahsedilen kumlar deniz kumudur ve kum kirlenince deniz de kirlenmektedir.)

Örnekte yer alan metin aracılı̆ııla verilen bu mesaj, okuyucuda "Kirli suların canlıları olumsuz etkileyebileceğini bilerek, oluşabilecek zararın önüne geçmek gereklidir." algısını oluşturabilir.

Kitapların \%1,7'sinde ( $\mathrm{n}=1$ ) (K18) "Suya Verilen Zararları Telafi Etmek İçin Diğerlerini Bilinçlendirmeliyiz." mesajının olduğu belirlenmiştir. Bu mesajla ilgili K18'dekiörnek metin ve görsel aşağıdaki gibi yer almaktadır: 


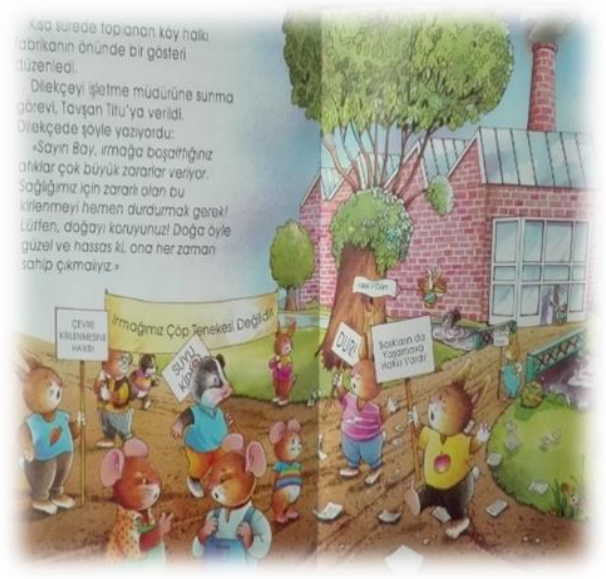

"Sayın Bay, ırmağa boşalttığınız atıklar çok büyük zararlar veriyor. Sağlığımız için zararlı olan bu kirlenmeyi hemen durdurmak gerek! Doğa öyle güzel ve hassas ki, ona her zaman sahip çıkmalıyız."

Örnekte yer alan metin ve görsel aracılığıyla verilen bu mesaj, okuyucuda "Suların temizlenebilmesi uygun yöntem belirlenerek diğer insanlarla paylaşılmalıdır." algısını oluşturabilir.

Tablo 4'te "Hava" temasıyla ilgili olarak 1 olumlu doğal çevre mesajının işlendiği görülmektedir.

Kitapların \%1,7'sinde ( $\mathrm{n}=1$ ) (K49) "Havaya Verilen Zararları Telafi Etmek İçin Diğerlerini Bilinçlendirmeliyiz." mesajının olduğu belirlenmiştir. Bu mesajla ilgili K49'daki örnek metin aşağıdaki

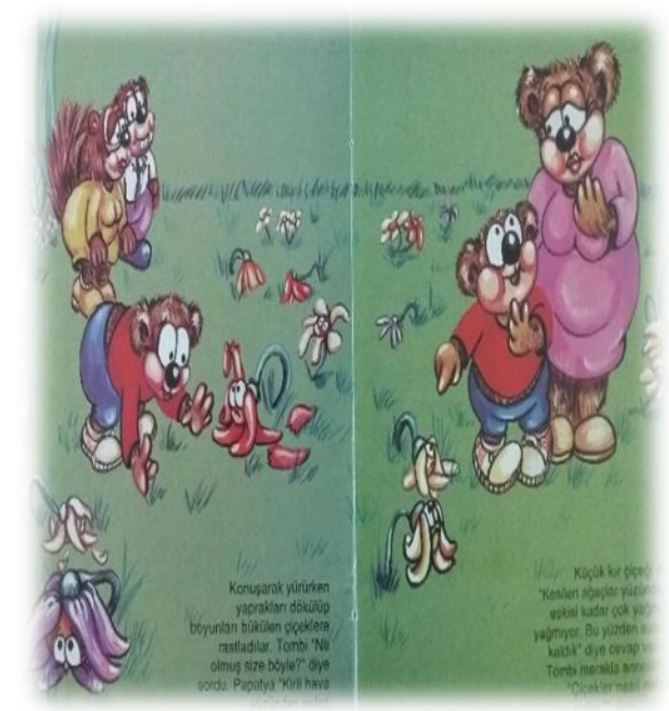
gibi yer almaktadır:

"Konuşarak yürürken yaprakları dökülüp boyunları bükülen çiçeklere rastladılar. Tombi 'Ne olmuş size böyle?' diye sordu. Papatya 'Kirli hava yüzünden nefes alamıoruz' dedi."

"Başkan onları dinledi: 'Çok haklısınız. ilk iş olarak bu anlattıklarınızı herkese duyurmalı, çevreyi kirletenleri uyarmalı ve onları eğitmeliyiz. Ayrıca, bizleri uyardığınız için de sizlere çok teşekkür ediyorum. Bu durumu düzeltmek için bizlere yardımcı olursanız çok sevinirim' dedi. Herkes çevreyi temiz tutup doğayı korumak için çok çalışmaya söz verdi. Görevlerini başarmanın mutluluğu içinde ormanlarına geri dönerlerken çok sevinçliydiler. Acaba bizler de çevremizi korumak için bir şeyler yapıyor muyuz?

Örnekte yer alan metin ve görsel aracıllğıyla verilen bu mesaj, okuyucuda "Havanın temizlenmesi için diğer insanlarla bir araya gelerek ortak çözüm yolları üretilmelidir." algısını oluşturabilir.

\section{b. Olumsuz Doğal Çevre Mesajları}

Tablo 4 incelendiğinde, 58 kitabın \%17,2'sinde ( $n=10)$ olumsuz doğal çevre mesajı verildiği görülmektedir. Bu mesajlara ilişkin bulgular aşağıda detaylı olarak verilmiştir: görülmektedir.

Tablo 4'te "Bitki" temasıyla ilgili olarak 1 olumsuz doğal çevre mesajının işlendiği

Kitapların \%10,3'ünde ( $n=6)(K 2, K 3, K 36, K 43, K 45$ ve K57) "Bitkilere İstediğimizde Zarar Verebiliriz." mesajının olduğu belirlenmiştir. Bu mesajla ilgili K2'deki örnek metin ve görsel aşağıdaki gibi yer almaktadır: 


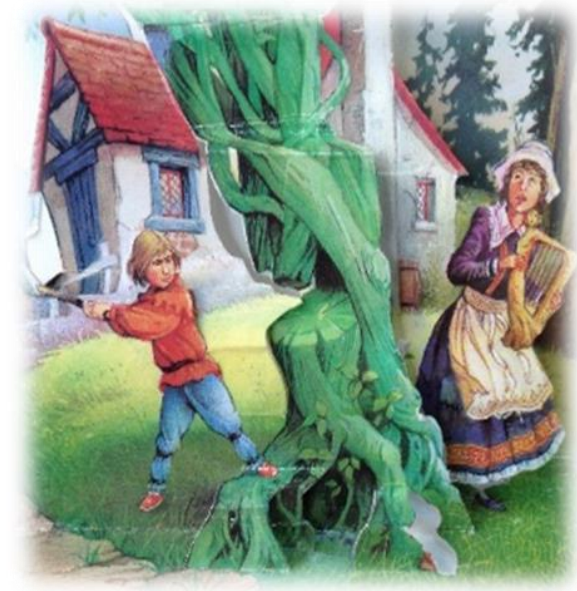

"Çabuk bana baltayı getir!' diye seslenmiş. Jack üç balta vuruşuyla fasulye ağacını yere sermiş."

Örnekte yer alan metin ve görsel aracılığıyla verilen bu mesaj, okuyucuda "Insanların çıkarları doğrultusunda bitkileri tahrip etmeleri kabul edilebilir bir durumdur." algısını oluşturabilir.

Tablo 4'te "Hayvan" temasıyla ilgili olarak 1 olumsuz doğal çevre mesajının işlendiği görülmektedir.

Kitapların \%5,2'sinde (n=3) (K6, K17 ve K46) "Hayvanlara İstediğimizde Zarar Verebiliriz." mesajının olduğu belirlenmiştir. Bu mesajla ilgili $K 6^{\prime}$ daki örnek metin ve görsel aşağıdaki gibi yer almaktadır:

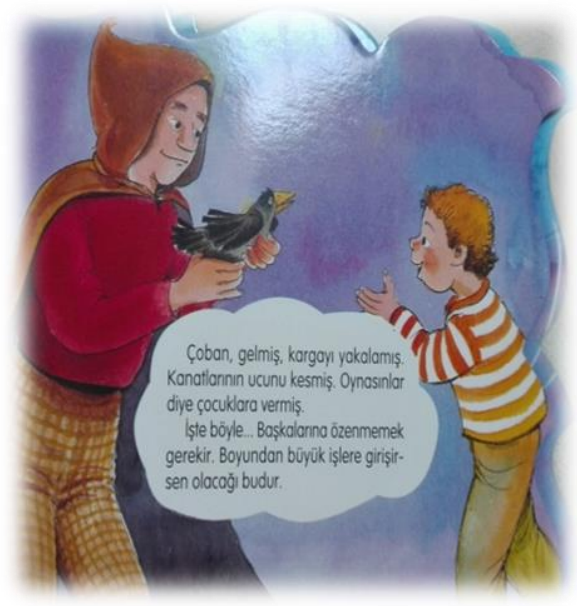

"Çoban, gelmiş, kargayı yakalamış. Kanatlarının ucunu kesmiş. Oynasınlar diye çocuklara vermiş."

Örnekte yer alan metin ve görsel aracılığıyla verilen bu mesaj, okuyucuda "Hayvanları incitmek ve onları oyuncak olarak kullanmak normal davranışlardır." algısını oluşturabilir.

Tablo 4'te "Su" temasıyla ilgili olarak 1 olumsuz doğal çevre mesajının işlendiği görülmektedir.

Kitapların \%1,7'sinde ( $\mathrm{n}=1$ ) (K58) "Suya Verilen Zararlara Tepkisiz Kalabiliriz." mesajının olduğu belirlenmiştir. Bu mesajla ilgili K58'deki örnek metin ve görsel aşağıdaki gibi yer almaktadır:

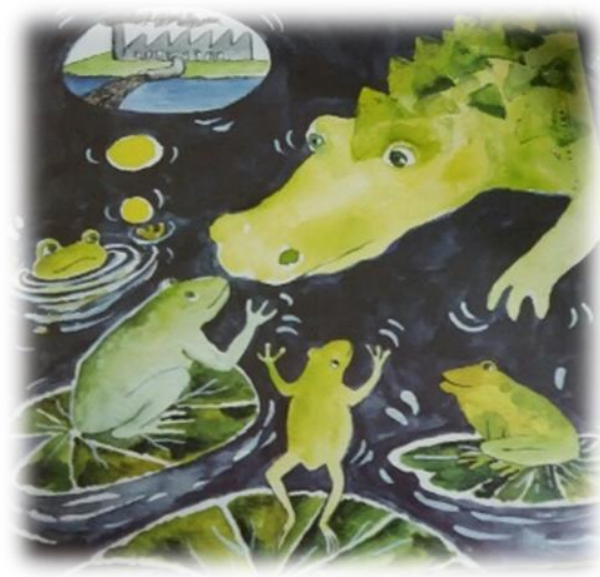

"Küçük kurbağa, peşinde yavrularıla beraber, ah! Sen de bir an evvel gitmelisin! Yeni yapılan fabrika, atıklarını bizim dereye boşaltıyor. Hastalanmadan bir an evvel uzaklaşmalıyız buradan!" 
Örnekte yer alan metin ve görsel aracılığıyla verilen bu mesaj, okuyucuda "iç̧inde yaşanılan çevre, doğa parçası kirlendiğinde, temizleme girişiminde bulunmadan terk edilebilir." algısını oluşturabilir.

\section{SONUÇ, TARTIŞMA VE ÖNERILER}

Bu araştırma ile incelenen 58 resimli öykü kitabının \%62,1'inin ( $n=36)$ doğrudan, \%37,9'ununise dolaylı olarakdoğal çevre konusuna değindiği sonucuna ulaşılmıştır. Benzer şekilde, Türkçe ve yabancı resimli öykü kitaplarının konularının incelendiği bir çalışmada; Türkçe resimli öykü kitaplarının 2. sırada "doğa-çevre" konusuna değindiği görülmüştür. Yabancı resimli öykü kitaplarının ise 3. sırada "hayvanlar" konusunu ele aldığı bulunmuştur (Uzmen, 1993). Gönen ve Güler (2011)'in araştırmalarında da, 2-12 yaş grubu çocuklara yönelik olarak 1995-2010 yılları arasında basılmış resimli öykü kitapları incelenmiş, incelenen kitapların \%80'inin konusunun çevre ile ilgili olduğu, bu kitapların \%22,5'inde ise doğa ve doğa kavramlarına yer verildiği tespit edilmiştir. Bu araştırma kapsamında incelenen kitapların, bahsi geçen iki araştırmada yer alan kitaplarla benzer şekilde, doğa konusunu işleme oranlarının yüksek olması, konunun güncelliğini koruduğunu göstermektedir. Kanat Soysal (2012)'ın yaptığı bir araştırmada, 1914-2008 yılları arasında yayımlanan çocuk kitaplarından 52'si incelenmiş, 1930'larda kahramanlık ve ulusal değerler; 1960'larda toplumculuk ve dayanışma; 1980 'lerde ve sonrasında ise duygular ve doğa-çocuk ilişkileri konularının yoğun olarak incelendiğini belirlemiştir. Bu araştırmada da, incelenen 58 kitabın (yayın yılı bilinmeyenler hariç) tamamının, 80 'lerden sonra hazırlandığı veişlenen konunun benzer olduğu görülmektedir. Yılmaz Genç ve Uyar (2016)'ın araştırmalarında da, bir olay örgüsü taşıyan resimli çocuk kitapları, fen eğitimine ilişkin kavram, konu ve temalara göre incelenmiştir. İçeriğinde fene ilişkin konu, kavram veya temalara rastlanan 112 resimli çocuk kitabında en çok ele alınan konunun hayvanlar olduğu ve en çok vurgu yapılan temanın ise canlıları tanıma olduğu belirlenmiştir. Bu araştırma sonuçlarına rağmen, Ankara'da resmi anaokullarında görevli 245 öğretmen tarafından en sık kullanılan 100 resimli öykü kitabının incelendiği araştırmada (Turan ve Ulutaş, 2016), kitapların yalnızca \%2,0'sinin taşıtlar, oyuncak, bitki, saygı, nesneler, alçakgönüllülük, barış, cesaret, çevre-doğa, yılbaşı, şekiller, liderlik, sağlık konularını ele aldığı görülmektedir. Bu konuda hazırlanan kitapların sayısının çok olması ve konunun güncelliğini koruyor olmasına rağmen, öğretmenlerin bu konudaki kitapları çok az kullanıyor olmaları, olumsuz yönde dikkat çekicidir.

Araştırma kapsamında incelenen resimli öykü kitaplarının \%67,2'sinde ( $n=39$ ) insan-doğal çevre etkileşimi, \%29,3'ünde ( $n=17$ ) hayvan-doğal çevre etkileşimi ve \%3,5'inde $(n=2)$ ise bitki-doğal çevre etkileşimi olduğu görülmektedir. Burada doğal çevre ile etkileşim kuran canlılar, kitaplardaki karakterlerdir. Aksine,Şahin ve Işıtan (2013)'ın 35'i çeviri, 45'i yerli olmak üzere toplam 100 çocuk edebiyatı ürünü üzerinde yaptıkları çalışmada da, üç-altı yaş çeviri ve yerli resimli çocuk kitaplarında en çok hayvan karakterlere yer verildiği görülmüştür. Hayvan karakterler yerli kitaplarda $\% 53,4$, çeviri kitaplarda \%71,4; insan karakterler yerli kitaplarda \%31,1, çeviri kitaplarda \%25,7 olarak belirlenmiştir. Benzer şekilde, Uğurlu (2013)'nun çalışması kapsamında incelenen resimli çocuk kitaplarında kullanılan karakter dağıımlarına bakıldığında, kitaplarda; \%41,1 oranında hayvan karakterine, \%36,6 oranında insan karakterine ve \%8,9 oranında doğal varlıklara yer verildiği tespit edilmiştir. Gönen, Karakuş, Uysal, Kehci, Ulutaş ve Kahve (2015)'nin araştırmalarında da, incelenen resimli öykü kitaplarındaki karakterlerin $\% 78$ 'inin hayvan, $\% 41$ 'inin insan ve $\% 22$ 'sinin ise bitki olduğu belirlenmiştir.Bu araştırma ilebahsi geçen üç araştırmanın çalışma gruplarının farklı olması nedeniyle farklı sonuçlara ulaşıldığı düşünülmektedir.

Araştırmada incelenen 58 resimli öykü kitabının \%82,8'inde ( $n=48$ ) olumlu, \%17,2'sinde $(n=10)$ ise olumsuz doğal çevre mesajı verildiği görülmektedir. Olumlu doğal çevre mesajı veren kitaplarda "Birden Fazla Doğa Unsuru" temasıyla ilgili olarak 3 doğal çevre mesajının (Doğa Unsurlarını Korumalıyız, Doğa Unsurlarını Korumak İçin Önlem Almalıyız, Doğa Unsurlarının Öneminin Farkına Varmalııız) yer aldığı görülmüştür. "Bitkiler" teması ile ilgili olarak 9 mesajın (Bitkilere Verilen Zararları Telafi Etmeliyiz, Bitkilere Verilen Zararları Telafi Etmeye Çalışmalıyız, Bitkilere Zarar Verme 
Endişesi Duymalıyız, Bitkilere Verilen Zararları Telafi Etmek İçin Plan Yapmalıyız, Bitkilerin Zarar Görmelerini Engellemeliyiz, Bitkilerin Canlı Varlıklar Olduklarının Farkına Varmalıyız, Bitkilere Zarar Vermekten Kaçınmalıyız, Bitkilerin Zarar Görmelerine Karşı Duyarlılık Göstermeliyiz, Bitkilerin Zarar Görmelerinin Olumsuz Sonuçlarının Farkına Varmalıyız) işlendiği görülmüştür. "Hayvanlar" temasıyla ilgili olarak 5 doğal çevre mesajının (Hayvanların Yaşam Alanlarının Farkına Varmalıyız, Hayvanlara Yardım Etmeliyiz, Hayvanların Canlı Varlıklar Olduklarının Farkına Varmalıyız, Hayvanların Yaşam Alanlarına Müdahale Etmemeliyiz, Hayvanlara Verilen Zararları Telafi Etmeye Çalışmalıyız) verildiği belirlenmiştir. "Toprak" temasıyla ilgili olarak 2 doğal çevre mesajının (Toprağa Verilen Zararları Telafi Etmeliyiz, Toprağa Verilen Zararları Engellemeliyiz) yer aldığı belirlenmiştir. "Su" temasıyla ilgili olarak 3 doğal çevre mesajının (Suya Verilen Zararların Farkına Varmalıyız, Suya Verilen Zararları Telafi Etmeliyiz, Suya Verilen Zararları Telafi Etmek İçin Diğerlerini Bilinçlendirmeliyiz) ele alındığı görülmüştür. "Hava" temasıyla ilgili olarak 1 doğal çevre mesajının (Havaya Verilen Zararları Telafi Etmek İçin Diğerlerini Bilinçlendirmeliyiz) işlendiği görülmüştür. En çok mesajın ise bitkiler konusunda olduğu belirlenmiştir. Benzer biçimde, Muthukrishnan ve Kelly (2016)'nin çocuk kitaplarında sürdürülebilirlik ile ilgili tasvirlerin olup olmadığı ve bu tasvirlerin çevre eğitimi hedeflerini destekleyip desteklemediğinibelirlemek amacıyla gerçekleştirdikleri araştırmalarında, kolay ulaşılabilen 7 çocuk kitabındaki 384 görseli analiz ederek doğa tasvirleri incelenmiştir. Resimlerin \%32'sinde ekosistemin geneli yerine bitkilerin resmedildiği tespit edilmiştir. Bu araştırma ile Muthukrishnan ve Kelly (2016)'nin çalışmalarının sonuçları, “bitkiler” konusundaki kitapların çokluğunu vurgularken günümüzde, yazarlar ve çizerlerin belki de en çok zararı gören bitkiler konusuna dikkati çekmeye çalıştığı söylenebilir.

Bu araştırmada ele alınan olumsuz doğal çevre mesajı veren resimli öykü kitaplarında "Bitki" temasıyla ilgili olarak 1 olumsuz doğal çevre mesajının (Bitkilere istediğimizde Zarar Verebiliriz), "Hayvan" temasıyla ilgili olarak 1 olumsuz doğal çevre mesajının (Hayvanlara İstediğimizde Zarar Verebiliriz) ve "Su" temasıyla ilgili olarak ise 1 olumsuz doğal çevre mesajının (Suya Verilen Zararlara Tepkisiz Kalabiliriz) işlendiği görülmektedir. Benzer şekilde, yapılan bir araştırmada, ABD'de en çok satan 0-8 yaş arası çocuk kitaplarında çevre temsilinin çevre eğitimi hedeflerine uygun olmadığı ve insanoğlunun çevre üzerine hâkimiyetini yansıttığı tespit edilmiştir (Boudreaux, 2006). Marriott (2002)'un araştırmasında da, doğal yaşamla ilgili incelenen 1074 resimli öykü kitabında, hayvanların doğal özelliklerinin yansıtılmadığı belirlenmiş ve bu tür kitaplar yoluyla çocukların doğa ile ilgili farkındalık kazanma olasılıklarının düşük oranlarda olabileceği vurgulanmıştır. Ahi, Yaya ve Özsoy (2014)'un 1989-2002 yılları arasında dünyanın 9 farklı bölgesinde basılmış doğa ve çevre konularının incelendiği 15 halk masalı üzerine gerçekleştirdikleri araştırmalarında da, 6 halk masalının insan-doğa etkileşimini incelediği ve bu masalların 2'sinin doğaya karşı olumsuz davranışları içerdiği belirlenmiştir. Bahsedilen üç araştırma ile bu araştırmada incelenen bazı kitapların içeriklerinin çocukların olumsuz etkilenebileceği şekilde hazırlandığı belirlenmiştir.

İncelenen 58 resimli öykü kitabının 48 'inde verilen olumlu doğal çevre mesajlarının, çocuk okuyucularda "Kağıt, plastik, cam gibi doğada uzun sürede çözünemeyen materyallerin, doğaya atılmayıp yeniden kullanılarak geri-dönüşümlerinin sağlanması konusunda diğerlerini uyarmalıyız." "Başka canlıların yaşam alanlarına saygılı olunmalıdır. Bu alanlara zarar verildiğinde, canlıların hayatlarının tehlikeye girebileceği düşünülmelidir.", "Kirli suların; temiz suları ve diğer doğa unsurlarını kirletebileceği bilinmelidir." gibi olumlu çevre algısının oluşmasına katkı sağlayabileceği öngörülmektedir. Buna karşılık, 58 kitabın 10'unda verilen olumsuz doğal çevre mesajlarının ise çocuk okuyucularda "Insanların çıkarları doğrultusunda bitkileri tahrip etmeleri kabul edilebilir bir durumdur.", "Hayvanları incitmek ve onları oyuncak olarak kullanmak normal davranışlardır." ve "Iç̧inde yaşanılan çevre, doğa parçası kirlendiğinde, temizleme girişiminde bulunmadan terk edilebilir." gibi olumsuz çevre algısı oluşturabileceği düşünülmektedir.

Okul öncesi dönem çocuklarının, küçük yaşta olmaları nedeniyle, edindikleri bilgi ve deneyimler, gelecek yaşamlarındaki davranışlarına yön verebilmektedir. Bu dönem çocuklarına yönelik resimli öykü kitabı yazarlarının, her konuda olduğu gibi, çevre konusuna da hassasiyet 
göstermeleri ve çocuklara olumlu doğal çevre mesajları vermeye dikkat etmeleri gerekmektedir. Aynı doğrultuda, bu dönem çocuklarına yönelik hazırlanan kitapların çizerleri de görsellerinde gizli ya da açık olarak verdikleri doğal çevre mesajlarını titizlikle gözden geçirmelidirler. Bu mesajların çocuklarda uygun olmayan çevre algılarına neden olabileceği gözden kaçırılmamalıdır.

Yayınevlerinin, resimli öykü kitapları hazırlama çalışmaları için çocuk gelişimi uzmanlarından, okul öncesi eğitimcilerinden, psikologlardan ve diğer ilgili meslek gruplarında görevli kişilerden oluşan bir komisyon ile çalışmaları önemlidir. Komisyonların, özellikle küçük yaş gruplarına yönelik yayınlanan resimli öykü kitaplarında yer alan metinlerle görselleri ayrıntılı biçimde inceleyerek istem dışı da olsa, olumsuz doğal çevre mesajı veren kitapları yayınlamamaları ya da yazar ile çizerleri konuyla ilgili uyararak gerekli düzeltmeleri yapmaları halinde kitapları yayınlamaları önerilir.

Okul öncesi eğitim kurumlarında çalışan sınıf, branş, kulüp öğretmenleri ve yardımcı öğretmenler ile öğretmen adayları, sınıflarında gerçekleştirdikleri, başta Türkçe etkinlikleri olmak üzere, tüm etkinliklerinde kullandıkları resimli öykü kitaplarının, her konuda olduğu gibi, çevre konularında da küçük yaş gruplarının gelişimsel özelliklerine uygunluğuna dikkat etmelidirler. Resimli öykü kitaplarını, ilk önce kendileri okuyarak bu kitaplardaki metin ve görsellerin verdiği doğal çevre mesajlarını dikkatle incelemeleri ve uygulamalarında olumlu doğal çevre mesajı ileten kitaplara yer vermelidirler. Ayrıca öğretmenler ve öğretmen adayları, kitaplarda belirledikleri olumlu doğal çevre mesajlarını, sınıf içinde vurgulayarak konuya dikkat çekmelidirler. Resimli öykü kitaplarında, istemsiz bir şekilde yansıtılan olumsuz çevre mesajlarını, çocuklarla tartışarak, çocuklukların doğal çevre konusunda olumlu algı geliştirmelerini desteklemelidirler.

Okul öncesi öğretmeni yetiştiren akademisyenler, kullandıkları kitaplarda verilen doğal çevre mesajlarının olumlu olması gerektiği konusunda, öğretmen adaylarını uyarmalıdırlar. Hizmet-içi eğitim seminerlerinde, öğretmenlere konu ile ilgili benzer şekilde uyarılar vererek öğretmenleri bilinçlendirmelidirler. Uygun derslerde ve seminerlerde olumlu doğal çevre mesajı veren kitapları kullanarak ilgili kitapların öğretmen adaylarına ve öğretmenlere tanıtımının sağlanması da yerinde olacaktır.

Okul öncesi dönem çocuklarına yönelik çalışmalar gerçekleştiren araştırmacıların, yaygın olarak kullanılan resimli öykü kitapları başta olmak üzere; çizgi filmler gibi görsel, çocuk şarkıları gibi işitsel uyaranlarda yer alan doğal çevre mesajlarını konu alan başka nitel ve nicel araştırmalar gerçekleştirerek alana katkıda bulunmaları gerekmektedir.

\section{KAYNAKLAR}

Adrian, J. E., Clemente, R. A., \& Villanueva, L. (2007). Mother's use of cognitive state verbs in picturebook reading and the development of children's understanding of mind: A longitudional study. Child Development, 78, 1052-1067.

Ahi, B., Yaya, D. ve Özsoy, S. (2014). The concept of environment in folktales from different cultures: Analysis of content and visuals. International Electronic Journal of Environmental Education, 4(1), 1-17.

Alan, H. A. (2015). Sustainable actions in picture storybooks for 4-to-6-year-olds: A content analysis study with respect to $7 R$. (Yayımlanmamiş yüksek lisans tezi). Sosyal Bilimler Enstitüsü, Orta Doğu Teknik Üniversitesi, Ankara.

Aslan, C. (2015). Çocuk edebiyatı yapıtlarının çevre sorunlarını yansıtışı bağlamında incelenmesi. Journal of Human Sciences, 12(2), 1818-1852.

Aydın, Y. ve Sevinç, Ö. S. (2016). Sürdürülebilirliğin karşısındaki engeller bağlamında Sait Faik öykülerinin çevresel sorunlar açısından sınıflandırılması ve değerlendirilmesi. Marmara Coğrafya Dergisi, 34, 244-252.

Ayvaz, Z.(1998). Çevre eğitimine giriş. İzmir: Çevre Eğitimi Merkezi Yayınları. 
Bacanlı, H.(2002). Gelişim ve öğrenme. Ankara: Nobel Yayınları.

Berg, B. L., \& Lune, H. (2015). Sosyal bilimlerde nitel araştırma yöntemleri. H. Aydın (Çev. Ed.) ve Y. Bulut ve B. Ercan (Çev.). Nitel araştırmayı desenleme. Konya: Eğitim Kitabevi.

Berk, L. E. (2001). Development through the lifespan. Boston, MA: Allyn and Bacon Publications.

Bozkurt, O. (2009). Çevre eğitimi. M. Aydoğdu ve K. Gezer (Ed.). Çevre bilimi. Ankara: Anı Yayıncılık.

Boudreaux, B. (2006). The Representation of the Environment in Children's Literature. . University of New Orleans Theses and Dissertations. Paper 335.

Bronfenbrenner, U. (1979). The ecology of human development: Experiments by design and nature. Cambridge, MA: Harvard University.

Bulut, P. ve Kuşdemir, Y. (2013). TÜBITAK tarafından yayınlanan çocuk kitaplarının içerik özelliklerinin incelenmesi. International Periodical for the Languages, Literature and History of Turkish or Turkic, 8(12), 215-226.

Bus, A. G., VanLzjendoorn, M. H., \& Pellegrini, A.D. (1995). Joint book reading makes for success in learning to read: A meta-analysis on integrational transmission of literacy. Review of Educational Research, 65(1), 1-21.

Büyüköztürk, Ş., Çakmak, E. K., Akgün, Ö. E., Karadeniz, Ş. ve Demirel, F. (2016). Bilimsel araştırma yöntemleri. Ankara: Pegem Yayınları.

Canbay, H. ve Edizer, Z. Ç. (2012). Behiç Ak'ın çocuk kitaplarında doğacı zeka. Gazi Üniversitesi Gazi Eğitim Fakültesi Dergisi, 32(1), 83-101.

Creswell, J.W. (2016). Karma yöntemler. S. B. Demir (Çev. Ed.) ve G. Hacıömeroğlu (Çev.). Nitel araştırma yöntemleri (s. 215-240). Ankara: Eğiten Kitap Yayıncılık.

Çabuk, B. (2000). Çocuk ve çevre. (Yayımlanmamış Yüksek Lisans Semineri.) Ankara Üniversitesi Fen Bilimleri Enstitüsü, Ankara.

Çabuk, B. (2001). Okul öncesi dönem çocuklarının çevre ile ilgili farkındalık düzeyleri. (Yayımlanmamış Yüksek Lisans Tezi.) Ankara Üniversitesi Fen Bilimleri Enstitüsü, Ankara.

Çakır İlhan, A. (1994). Çocuk kitaplarındaki resimlerin çocuğun yaratıcılığına etkisi. Yaşadıkça Eğitim, $36,27-29$.

Çılgın Sınar, A. (2007). Çocuk edebiyatı. İstanbul: Morpa Kültür Yayınları.

Dağlıoğlu, H. E. ve Çamlıbel Çakmak, Ö. (2009). Okul öncesi çocuklarına yönelik yayınlanan hikaye kitaplarının şiddet ve korku ögeleri açısından incelenmesi, Türk Kütüphaneciliği, 23(3), 510-534.

Dinçer, Ç. (1999) Okulöncesi dönem çocuklarında çevresel farkındalıkları artırma yolları. Çevre ve insan, 44, 28-31.

Erden, M ve Akman, Y. (2006). Gelişim ve öğrenme. Ankara: Arkadaş Yayınları.

Erdener, E. (2009), Vygotsky'nin Düşünce ve Dil Gelişimi Üzerine Görüşleri: Piaget'e Eleştirel Bir Bakış. Türk Eğitim Bilimleri Dergisi 7(1), 85-103.

Fırat, H., Güleç H. ve Şahin, Ç. (2013). Okul öncesi dönem çocuklarına yönelik hazırlanan masal ve öykü kitaplarının korku ve şiddet öğeleri açısından incelenmesi. The Journal of Academic Social Science Studies, 6(5), 217-241.

Glesne, C. (2012). Nitel araştırmaya giriş. A. Ersoy ve P. Yalçınoğlu (Çev. Ed.) ve E. Günel (Çev.). Nitel araştırmayla tanışma (s. 1-36). Ankara: Anı Yayıncılık. 
Gökçe, B. ve Sis, N. (2011). Gülten Dayıoğlu'nun çocuk öykülerinin "Hikaye Haritası" yöntemine göre incelenmesi ve genel bir değerlendirme. International Periodical for the Languages, Literature and History of Turkish or Turkic, 6(3), 1925-1949.

Gönen, M. (2000). Resimli çocuk kitaplarının içerik, resimleme, fiziksel özellikleri ve Türkiye'de son on yılda çocuk kitapları alanında yapılmış tezler. 1. Ulusal Çocuk Kitapları Sempozyumu Bildiri Kitabı. Ankara Üniversitesi, Ankara.

Gönen, M. ve Güler, T. (2011). The environment and its place in children's picture story books. Procedia Social and Behavioral Sciences, 15, 3633-3639.

Gönen, Karakuş, Uysal, Kehci, Ulutaş ve Kahve (2015). Resimli çocuk kitaplarının içerik ve resimleme özelliklerinin bazı değişkenler açısından incelenmesi. Hacettepe Üniversitesi Eğitim Fakültesi Dergisi, 31(4), 724-735.

Gönen, M. ve Uyanık Balat, G. (2002). Çocuk kitaplarına yeni bir yaklaşım: İnternette resimli öykü kitapları. Türk Kütüphaneciliği, 16(2), 163-170.

Güner, Z. ve Kesicioğlu, T (2012). Okul öncesi çevre eğitimi için alternatif bir yaklaşım: farklılaştırılmış öğretim. (Yayımlanmamış doktora tezi). İstanbul Teknik Üniversitesi Fen Bilimleri Enstitüsü, İstanbul.

Güneş, Z. (2007). Ilköğretimde çocuk edebiyatı. Eskişehir: Anadolu Üniversitesi Açık Öğretim Fakültesi Yayınları, 67-68.

Haktanır, G. (2007). Okul öncesi dönemde çevre eğitimi içinde: Çevre eğitimi. Türkiye Çevre Eğitimi Vakfı Yayını, 178, 11-34.

Hamamcı, C. ve Keleş, R. (1998). Çevrebilim. Ankara: İmge Kitabevi.

Harris, M., \& Butterworth, G. (2002). Development psychology. New York: Taylor \&Francis Inc.

Hochberg, J. \& Brooks, V. (1962). Pictural recognition as an unlearned ability: A study of on child's performance. Journal of Psychology, 75(4), 624-628.

Ileri, R.(1998). Çevre eğitimi ve katılımın sağlanması. Çevre Koruma Dergisi, 28, 3-9.

Jersild, A. (1979). Çocuk psikolojisi. G, Günce (Çev.). Ankara: Ankara Üniversitesi Eğitim Bilimleri Fakültesi Yayınları.

Kanat Sosyal, Ö. (2012). Çağdaş Türk çocuk edebiyatının gelişimi: Tevfik Fikret'ten Fazıl Hüsnü Dağlarca'ya (1914-2008). (Yayımlanmamış yüksek lisans tezi). Ankara Üniversitesi.

Kara, C. (2012). Çocuk kitabı seçiminde resimlemelerle ilgili olarak ebeveynin dikkat etmesi gereken başlıca unsurlar. Batman University Journal of Life Sciences, 1(1), 225-232.

Karacan, E. (2000). Bebeklerde ve çocuklarda dil gelişimi. Klinik Psikiyatri Dergisi, 3(4), 263-268.

Karataş, Z. (2015). Sosyal bilimlerde nitel araştirma yöntemleri. Manevi Temelli Sosyal Hizmet Araştırmaları Dergisi, 1(1), 62-80.

Kuzu, T. (2007). Aytül Akal'ın masallarıyla çocukta çevre bilinci geliştirme. Selçuk Üniversitesi Sosyal Bilimler Enstitüsü Dergisi, 19, 327-339.

Kürkçüoğlu, B. (2010). 0-6 yaş arası çocukların temel gelişimsel özellikleri: Bilişsel gelişim ve dil gelişimi. I. Diken ( Ed.). Erken Çocukluk Eğitimi. Ankara: Pegem Yayıncılık.

Ludlow, B. L., \& Berkeley, T. R. (1994). Expanding the perceptions of developmentally appropriate practice: Changing theoretical perspectives. Diversity and developmentally appropriate practices. New York: Teachers College Press. 
Lüle, E. (2007). Yedi farklı çocuk kitabının çocuk yazını ilkelerine uygunluğunun değerlendirilmesi. Inönü Üniversitesi Eğitim Fakültesi Dergisi, 8(4), 17-30.

Mardi, H. Ö. (2006). Çocuk kitapları resimlemede karakter yaratma. (Yayımlanmamış yüksek lisans tezi). Dokuz Eylül Üniversitesi, İzmir.

Marriott, S. (2002). Red in Tooth and Claw: Images of nature in modern picture books. Children's Literature in Education, 33(3), 175-183.

Merriam, S. B. (2013). Nitel araştırma desen ve uygulama için bir rehber. S. Turan (Çev.). Ankara: Anı Yayıncilık.

Morgil, I., Ural, E., Erdem, E., Oskay, Ö., ve Yılmaz, A. (2005). Kimya eğitiminde çevre, çevre sorunları ve alternatif çözümler konusundaki workshop çalışmasının öğrenci performansına etkisi. XIV. Ulusal Eğitim Bilimleri Kongresi Bildiriler Kitabı, 586-588.

Muthukrishnan, R., \& Kelly, J. E. (2016). Depictions of sustainability in children's books. Environment, Development and Sustainability, 18(1), 1-16.

Oktay, A. (1998). Okul öncesi dönemi (3-6 yaş) ana baba okulu. İstanbul: Remzi Kitabevi.

Orr, D. W. (1990). Environmental education and ecological literacy. The Education Digest, 55(9), 49.

Patton, M. Q. (2002). Nitel araştırma ve değerlendirme yöntemleri. M. Bütün ve S. B. Demir. (Çev.). Ankara: Pegem Akademi.

Ross, V. (1989). Annals of child development. London: Jessical Kingsley Publications.

Saban, A. ve Ersoy, A.(2016). Eğitimde nitel araştırma desenleri. Ankara: Anı Yayıncılık.

Senemoğlu, N. (2007). Gelişim, öğrenme ve öğretim - kuramdan uygulamaya. Ankara: Gönül Yayınları.

Sever, S. (2003). Çocuk ve edebiyat. Ankara: Kök Yayıncılık.

Sever, S. (2010). Çocuk ve edebiyat. İzmir: Tudem Yayınları.

Soydan, K. (2014). Türk kültürüne göre çocuk hikaye kitaplarında illüstrasyon. (Yayımlanmamış doktora tezi). İstanbul Arel Üniversitesi, İstanbul.

Şahin, N. F., Cerrah, L., Saka, A. ve Şahin, B. (2004). Yüksek öğretimde öğrenci merkezli çevre eğitimi dersine yönelik bir uygulama. Gazi Eğitim Fakültesi Dergisi, 3(24),113-128.

Şahin, S. ve Işıtan, S. (2013) "Yerli ve çeviri okulöncesi çocuk kitaplarının karakter, benlik kavramı ve prososyal davranışlar açısından incelenmesi". III. Ulusal Çocuk ve Gençlik Edebiyatı Sempozyumu Bildiri Kitabı. s. 1021-1028. 05-07 Ekim 2011 ÇOGEM. Ankara: Ankara Üniversitesi Basımevi.

Şimşekli, Y. (2004). Çevre bilincinin geliştirilmesine yönelik çevre eğitimi etkinliklerine ilköğretim okullarının duyarlılı̆̆ı. Uludağ Üniversitesi Eğitim Fakültesi Dergisi, 17(1), 83-92.

Taşdelen, V. (2016). Çocuk edebiyatında görsel öge. Çocuk ve Medeniyet Dergisi, 1, 123-135.

Temizyürek, F. ve Çevik, A. (2014). Mustafa Ruhi Şirin'in çocuk edebiyatı sahasındaki eserlerinin dil ve kavram bağlamında incelenmesi. Bartın Üniversitesi Eğitim Fakültesi Dergisi, 3(1), 155-175.

Turan, F., ve Ulutaş, İ. (2016). Okul öncesi eğitim kurumlarındaki resimli öykü kitaplarının özellikleri ile öğretmenlerin bu kitapları kullanma durumlarının incelenmesi. Hacettepe University Graduate School of Educational Sciences The Journal of Educational Research, 2(1), 21-45 
Turpoğlu Çelik, A. (2015). Erken çocukluk döneminin, aile ve toplum sağlığı ile demokrasi ve toplumsal gelişim üzerindeki etkileri ve yapılması gereken yatırım ve müdahaleler. Akademik Sosyal Araştırmalar Dergisi, 13, 240-263.

Tür, G. ve Turla, A. (1999). Okul öncesinde çocuk, ebediyat ve kitap. İstanbul: YA-PA Yayınları.

Uğurlu, S. B. (2013). Resimli çocuk kitaplarında hayvan karakter kullanımı. International Periodical for the Languages, Literature and History of Turkish or Turkic, 8(4), 1381-1393.

Uzmen, S. (1993), "1970-93 yılları arasında basılmış türkçe ve ingilizce resimli hikaye kitaplarının konu yönünden incelenmesi”. (Bilim Uzmanlığı Tezi). Hacettepe Üniversitesi Çocuk Sağlığı ve Eğitimi Programı, Ankara.

Vygotsky, L. (1978). Mind and society. Cambridge, MA: Harward University Press.

Wilson, R. (2008). Nature and young children: Encouraging creative play and learning in natural environments. Abingdon: Routledge.

Wilson, R. A. (1994). Environmental education at the early childhood level. Day Care and Early Education, 22(2), 23-25.

Yapıcı, Ş. (2006). Çocukta dil gelişimi. Journal of Human Sciences, 1(1), 1-17.

Yıldırım, A. ve Şimşek, H. (2011). Sosyal bilimlerde nitel araştırma yöntemleri. Ankara: Seçkin Yayıncilık.

Yıldırım, K. (2010). Nitel araştırmalarda niteliği artırma. ilköğretim Online, 9(1), 79-92.

Yılmaz Genç, M. M. ve Özen Uyar, R. (2016). Resimli çocuk kitaplarının fene yönelik kavram, konu ve temalar açısından incelenmesi. Journal of International Social Research, 9(46), 600-607.

Yin, R. K. (2013). Case study research: Design and methods. Beverly Hills, CA: SAGE publications. 


\section{SUMMARY}

Picture storybooks, one of the leading materials of children's literature, which is crucial for children's language development, especially in preschool, make it easier to acquire information through illustrations. When children meet picture storybooks, they can easily access visual information through the illustrations and written information by the texts. The illustrations that reflect the content of the language used through texts in picture storybooks are the greatest supporters of teachers on effective teaching (Soydan, 2014).

The purpose of this qualitative study was to examine the illustrations and texts in the picture storybooks for 3-to-6-year-old children with respect to positive and negative natural environment messages. In the light of this purpose, these questions were investigated: (1) Are preschool picture storybooks directly/indirectly related with the topic of natural environment? (2) Which types of living organism-natural environment interactions are found in preschool picture storybooks? (3) Which types of positive/negative natural environment messages in terms of living organism-natural environment interaction are contained in the illustrations and texts in the preschool picture storybooks? (4) What are the perceptions of natural environment in children which can be formed by positive/negative natural environment messages in the illustrations and texts in the preschool picture storybooks?

For this case study, the study, data was collected by three forms developed by the researchers. These forms are: (1) "Book Classification Form" used for determining living organism-natural environment interactions, (2) "Book Information Form" used for recording the selected books and (3) "Natural Environment Messages Form" used for determining the positive/negative natural environment messages given in pictures storybooks.

In this study, books which are appropriate for the selected criteria among 8077 books in Children's Library located in a university were analyzed. After defining the criteria, 954 books which are suitable for 3-to6 -year-old children were selected. Then, second and third copies of the books were eliminated and the remaining books ( $n=671$ ) were examined by the researchers interactively. In the next step, researchers decided whether books have direct/indirect living organism-natural environment interaction and therefore 79 picture storybooks were chosen for analysis. Afterwards, these 79 picture storybooks were crosswised by the researchers to continue analysis individually. Finally, with 58 picture storybooks which researchers agreed to have positive/negative natural environment messages, analysis were completed.

It was found out that $62.1 \%$ of 58 picture storybooks $(n=36)$ were directly related with natural environment and $37.9 \%$ of these books $(n=22)$ were indirectly related with natural environment. It was stated that out of 58 books, $67.2 \%$ of them ( $n=39$ ) have human-natural environment interaction, $29.3 \%$ of them $(n=17)$ have animal-natural environment interaction and $3.5 \%$ of them $(n=2)$ have plant-natural environment interaction. At this, the living organism which interacts with the natural environment is the character which is in the book.

$82.8 \%$ of 58 books $(n=48)$ examined in the study have positive natural environment messages and $17.2 \%$ of these books $(n=10)$ have negative natural environment messages. Given positive natural environment messages in the books with the theme of "more than one nature element", there are 3 natural environment messages. ("We should protect nature elements.", "We should take precaution to protect nature elements.", "We should be aware of the importance of nature elements.")

Given positive natural environment messages in the books with the theme of "plants", there are 9 natural environment messages. ("We should recover the damages given to plants.", "We should try to recover the damages given to plants.", "We should be concerned about plants to be damaged.", "We should plan to recover the damages given to plants.", "We should prevent the plants from damages.", "We should be aware that plants are living organisms.", "We should avoid the plants to be damaged.", "We should be sensitive for plants not to be damaged.", "We should be aware of negative results of the damages given to plants.")

Given positive natural environment messages in the books with the theme of "animals", there are 5 natural environment messages. ("We should be aware of the animals' habitats.", "We should help animals.", "We should be aware that animals are living organisms.", "We should not be interfere in animals' habitat.", "We should try to recover the damages given to animals.")

Given positive natural environment messages in the books with the theme of "earth", there are 2 natural environment messages. ("We should recover the damages given to earth.", "We should prevent the earth from damages.")

Given positive natural environment messages in the books with the theme of "water", there are 3 natural environment messages. ("We should be aware of the damages given to water.", "We should recover the damages given to water.", "We should raise awareness of others to recover the damages given to water.") 
Given positive natural environment messages in the books with the theme of "air", there is 1 natural environment message. ("We should raise awareness of others to recover the damages given to air.")

It is showed that the most messages were given in the topic of "plants".

The message given by the example text and illustration may create a perception in the readers like "If the nature and, in particular, the trees are protected and water pollution is prevented, the water will remain clean. If the soil is consciously processed, the product is obtained in abundant quantities. Protecting nature is the benefit of all living things."

Given negative natural environment messages in the books with the theme of "plants", there is 1 natural environment message ("We can damage plants when we want to."), with the theme of "animals", there is 1 natural environment message ("We can damage animals when we want to"), with the theme of "water", there are 1 natural environment message ("We can remain unresponsive to the damages given to water"). 